\title{
Adaptive Crop Management under Climate Uncertainty: Changing the Game for Sustainable Water Use
}

\author{
Soe W. Myint ${ }^{1, *}$, Rimjhim Aggarwal ${ }^{2}{ }^{(}$, Baojuan Zheng ${ }^{3}$, Elizabeth A. Wentz ${ }^{1}$, Jim Holway ${ }^{4}$, Chao Fan ${ }^{5}$, \\ Nancy J. Selover ${ }^{6}$, Chuyuan Wang ${ }^{7}\left(\mathbb{D}\right.$ and Heather A. Fischer ${ }^{8}$ \\ 1 School of Geographical Sciences and Urban Planning, Arizona State University, Tempe, AZ 85287, USA; \\ wentz@asu.edu \\ 2 School of Sustainability, Arizona State University, Tempe, AZ 85287, USA; rimjhim.aggarwal@asu.edu \\ 3 Geospatial Sciences Center of Excellence, South Dakota State University, Brookings, SD 57006, USA; \\ baojuan5@vt.edu \\ 4 Babbitt Center for Land and Water Policy, Lincoln Institute of Land Policy, Phoenix, AZ 85028, USA; \\ jholway@lincolninst.edu \\ 5 Department of Geography, University of Idaho, Moscow, ID 83844, USA; cfan@uidaho.edu \\ 6 Arizona State Climate Office, Arizona State University, Tempe, AZ 85287, USA; selover@asu.edu \\ 7 Department of Geography and Environmental Planning, Towson University, Towson, MD 21252, USA; \\ cwang@towson.edu \\ 8 Center for Research on Lifelong STEM Learning, Oregon State University, Corvallis, OR 97331, USA; \\ heather.fischer@oregonstate.edu \\ * Correspondence: Soe.Myint@asu.edu
}

check for updates

Citation: Myint, S.W.; Aggarwal, R.; Zheng, B.; Wentz, E.A.; Holway, J.; Fan, C.; Selover, N.J.; Wang, C.; Fischer, H.A. Adaptive Crop Management under Climate Uncertainty: Changing the Game for Sustainable Water Use. Atmosphere 2021, 12, 1080. https://doi.org/ 10.3390/atmos12081080

Academic Editor: Gianni Bellocchi

Received: 19 July 2021

Accepted: 17 August 2021

Published: 23 August 2021

Publisher's Note: MDPI stays neutral with regard to jurisdictional claims in published maps and institutional affiliations.

Copyright: (C) 2021 by the authors Licensee MDPI, Basel, Switzerland. This article is an open access article distributed under the terms and conditions of the Creative Commons Attribution (CC BY) license (https:/ / creativecommons.org/licenses/by/ $4.0 /)$.

\begin{abstract}
Water supplies are projected to become increasingly scarce, driving farmers, energy producers, and urban dwellers towards an urgent and emerging need to improve the effectiveness and the efficiency of water use. Given that agricultural water use is the largest water consumer throughout the U.S. Southwest, this study sought to answer two specific research questions: (1) How does water consumption vary by crop type on a metropolitan spatial scale? (2) What is the impact of drought on agricultural water consumption? To answer the above research questions, 92 Landsat images were acquired to generate fine-resolution daily evapotranspiration (ET) maps at $30 \mathrm{~m}$ spatial resolution for both dry and wet years (a total of 1095 ET maps), and major crop types were identified for the Phoenix Active Management Area. The study area has a subtropical desert climate and relies almost completely on irrigation for farming. Results suggest that there are some factors that farmers and water managers can control. During dry years, crops of all types use more water. Practices that can offset this higher water use include double or multiple cropping practice, drought tolerant crop selection, and optimizing the total farmed area. Double and multiple cropping practices result in water savings because soil moisture is retained from one planting to another. Further water savings occur when drought tolerant crop types are selected, especially in dry years. Finally, disproportionately large area coverage of high water consuming crops can be balanced and/or reduced or replaced with more water efficient crops. This study provides strong evidence that water savings can be achieved through policies that create incentives for adopting smart cropping strategies, thus providing important guidelines for sustainable agriculture management and climate adaptation to improve future food security.
\end{abstract}

Keywords: crop type; evapotranspiration; Landsat; water consumption; drought; multiple cropping practices

\section{Introduction}

The Fourth National Climate Assessment completed in 2017 documents that annual precipitation has declined in much of the U. S. West, Southwest, and Southeast [1]. In the Southwest specifically, climate records show that droughts are a frequent occurrence including some of the longest documented "mega droughts" on Earth [2]. Mega droughts 
are associated with reduced precipitation, increased evaporation, elevated temperatures, and increased water demand from plants, which in turn facilitates even longer and more intense droughts [3-5]. These and other factors are resulting in significant declines in the flow of the Colorado River and raising numerous water conservation and management concerns [3,6-8]. The Colorado River basin is a major source of water for 33 million people in the U.S. and an additional 3 million people in Mexico for domestic consumption, industrial uses, and irrigated agriculture [9].

Much of the Colorado River flows through desert environments of the U.S. Southwest. These desert environments are projected to become drier and warmer more rapidly than other climate regions $[10,11]$. Since most deserts are already drastically hot, and hostile additional warming is likely to be exceptionally damaging to their ecosystems [12]. It can be expected that these stressors to freshwater ecosystems will continue to intensify as demands for water resources rise in connection to uncontrollable urbanization and expansion of agriculture for food security [13-15]. Inappropriate land use land cover changes, overwhelming population growth, and adverse environmental impacts due to climate change will augment pressure on groundwater and are likely to trigger nonrecoverable depletion [16].

Reduced water availability combined with competing water demands from multiple sectors results in an emerging urgent need to improve the efficiency of agricultural water use, a critical global water adaptation strategy. Projected water scarcity is driving competition among farmers, energy producers, and urban dwellers [17]. Even though agriculture is the largest water use sector in the U.S. Southwest, urban water demand is project to increase $80 \%$ by 2030 [18-20]. This could mean that neither sector reaches their estimated future water demands [21].

There is significant promise in understanding large-scale agricultural water use, particularly during mega droughts, by monitoring and measuring cropland evapotranspiration (ET). ET is the measurable amount of water vapor from evaporation from the land surface and transpired from plants. From a climate change perspective, an important question is regarding how ET varies between dry and wet years. In the case of the high-altitude basins in the Sierra Nevada, California, it was found that dry years are typically associated with higher potential ET due to higher surface temperatures in the summer months, greater solar radiation exposure due to lower cloud cover, greater vapor pressure deficit, and longer growing seasons [22]. However, dry years also have limited moisture availability compared to wet years, and thus the actual ET is much less than the potential ET in dry years. The difference between ET in dry and wet years is expected to be different in irrigated areas, as the availability of irrigation may alleviate the limitation posed by naturally available moisture. In irrigated areas, the actual ET can be expected to be closer to the potential ET, which may be higher in dry years than wet years. This is true for most crops in an arid region. If naturally available moisture is limited (due to absence of irrigation), actual ET is lower than potential ET. As plants close their stomata and reduce transpiration [23] and soils dry out earlier [24], actual ET becomes lower. If irrigation is available, actual ET is closer to potential ET [22]. Higher actual ET in dry years compared to wet years suggests that consumptive use of water in agriculture can be greater in dry years while competition from other water use sectors is most intense. This makes irrigation water management very challenging, particularly in urban and peri-urban areas where competing demand for higher value water uses is high. This is the case in our study region, the Phoenix Active Management Area (AMA), where agriculture accounts for nearly $40 \%$ of total water use and faces intense competition from municipal uses, particularly in dry years.

Agricultural stakeholders were enthused about the idea of using remote sensing data to estimate ET rates. Water managers in the state were interested to explore the potential of using the estimated ET rates to better plan for water allocations, especially during drought conditions. The third Management Plan of the Phoenix AMA produced by the Arizona Department of Water Resources (ADWR) notes that "it is not known for certain how many acres are in production on an annual basis. Lack of information on farming practices 
such as double cropping, crop rotation, and land fallowing also makes it difficult to assess annual water demand" [25]. There was an emerging need to explore how our study could contribute to filling this important gap.

The goal of this study was to answer two overarching research questions on agriculture and drought: (1) How does water consumption vary by crop type on a large spatial scale? (2) What is the impact of drought on agricultural water consumption? To answer these research questions, this study generated and employed fine-resolution daily ET maps at $30 \mathrm{~m}$ spatial resolution for both dry and wet years in the Phoenix AMA. This resulted in 1095 ET maps over the study area to estimate water use. This is complemented with crop type mapping using 92 Landsat scenes. Answers to these questions are expected to generate solutions on the adaptive options to manage water through changes in crop mixes.

Using this data, the specific objectives of this study were to: (1) examine which crop types use more water and evaluate how this consumptive use for different crops varies across dry years versus wet years; (2) show how much water can be saved by switching from single crops to double cropping practices; (3) demonstrate for dry years how much more water needs to be used by each crop type, including double crops; (4) provide data on water consumption per crop for both dry and wet years and show how much water can be saved by growing double crops; and (5) illustrate how much water can be saved by switching from two single crops to double cropping practices and by switching from double cropping with water intensive crops to double cropping with less water intensive crops.

While this project was ongoing (2012-2015), Arizona was in the midst of a long-term drought, and towards the end of our grant period (the latter half of 2014), there was a significant probability of an official declaration of shortage in the Colorado River water supply starting around 2016. Around 40\% of the requirement for water for agricultural use in Phoenix AMA is met through the aqueduct, the Central Arizona Project (CAP). Under shortage conditions, CAP is subject to reductions in Colorado River water because CAP holds a "junior" water entitlement to Colorado River water among the Lower Basin states (Arizona, California, and Nevada). Under the shortage guidelines, it is stipulated that CAP would limit its water deliveries to non-Indian agricultural consumers first before cutting deliveries for municipal uses. The strong likelihood of a shortage declaration in the near future caused significant concern among farmers in Phoenix AMA, and there was a great deal of interest in exploring alternative options for adaptation. For this project, annual workshops with agricultural stakeholders were conducted to engage them with the research process and explore how our research could be made meaningful given their needs and priorities.

\section{Study Area}

This study focused on an important agriculture region of the desert southwest of the US-the Phoenix AMA. The Phoenix AMA is located in central and south-central Arizona and consists of five groundwater basins (Figure 1).

While there are seasonal rain patterns in the study area, annual average precipitation is typically less than $180 \mathrm{~mm}$ /year, leading to nearly $100 \%$ reliance on irrigation. Rapid population growth and urbanization led to the conversion of many agricultural lands for development. This changed the water use dynamics in the region, the extent and the impacts of which have not been explored in depth. The Phoenix AMA includes East Salt River Valley (ESRV), West Salt River Valley (WSRV), Hassayampa, Rainbow Valley, Fountain Hills, Lake Pleasant, and Carefree ground water sub-basins. The Phoenix AMA is the largest of Arizona's five Active Management Areas at approximately 1,462,307 hectares and a consumption rate of 284 million cubic meters of water annually. The basin is drained by five major rivers, Salt, Gila, Verde, Agua Fria, and Hassayampa, and receives surface water from the state's largest water producing watershed, the Salt and the Verde, which converge in the Phoenix AMA. Elevations range from $230 \mathrm{~m}$ where the Gila River exits the basin to almost $1798 \mathrm{~m}$ in the New River Mountains on the northern basin boundary [25]. It is characterized by Sonoran Desert valleys surrounded by mid-elevation mountain ranges. 
The Phoenix AMA has a subtropical desert climate with average annual temperature of $21^{\circ} \mathrm{C}$ and a bimodal seasonal rainfall pattern; most rainfall occurs from December to March and from July to September [26]. The average total annual precipitation is $230 \mathrm{~mm}$ [25]. Thus, the area relies on irrigation for farming, which used about $47 \%$ of all water used in Phoenix AMA during the period from 2001 to 2005 [25].

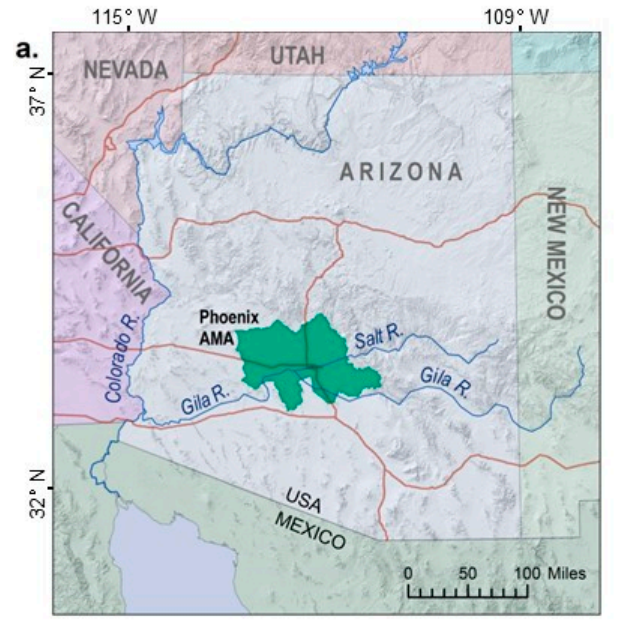

b.

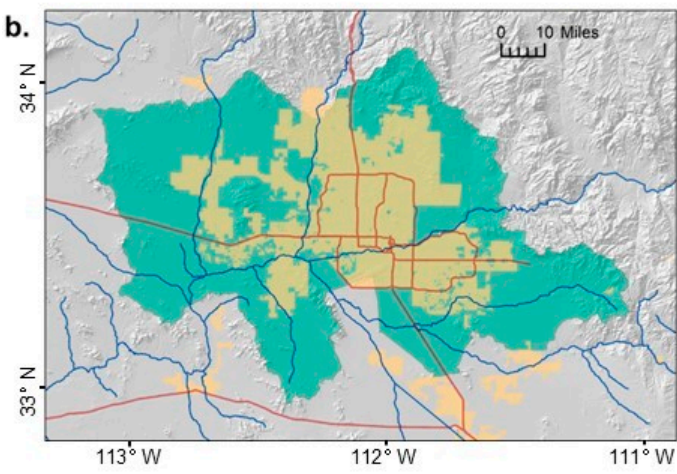

c.

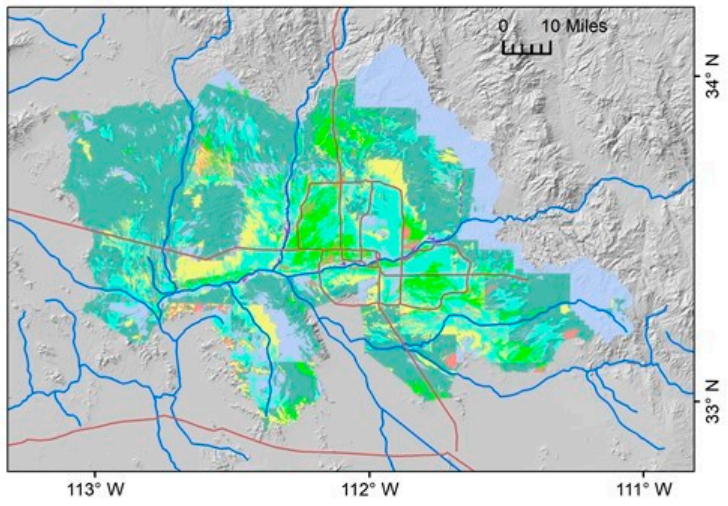

Soil types
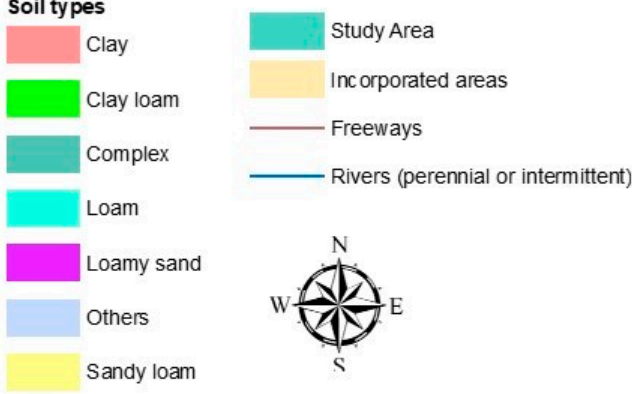

Figure 1. Phoenix Active Management Area (Phoenix AMA) Basin. (a) Phoenix AMA located in Arizona and neighboring states, (b) Phoenix AMA, (c) soil map of Phoenix AMA.

\section{Materials and Methods}

One dry year (2002) and two wet years (2001 and 2005) were selected to conduct the proposed research. Since dry years and wet years were determined based on water calendar (October to September) by the Arizona State Climate Office, and ET estimation was based on the calendar year (January to December), only significant dry and wet years based on calendar years were considered. Even though a particular year is listed as a dry year (based on a water year), it is not considered a dry year if the dry condition is not consistent throughout January to December (calendar year). It should be noted that dry and wet years were determined by watersheds, and there were a few watersheds in the study area. We considered most watersheds in the Phoenix AMA to determine significant dry or wet years. Hence, there were only a few years that could be considered dry and wet years. We employed 29 Landsat scenes (13 Landsat $7+16$ Landsat 5) for 2001 (wet year), 29 Landsat scenes (16 Landsat $7+13$ Landsat 5) for 2002 (dry year), and 34 Landsat scenes (22 Landsat $7+12$ Landsat 5) for 2005 (wet year).

\subsection{Prediction of ET}

One of the most important land surface parameters that can be derived from remote sensing is actual ET. Spatiotemporal distribution of ET is needed for a better understanding of water and energy exchange processes that impact biological communities and describe 
amounts and variation in soil-water storage in the hydrologic cycle. Quantification of ET is needed to support sustainable management of water resources. Because ET has high spatial variability, satellite-based estimation is necessary to extend flux measurements from essential point locations over large landscapes [27-29]. The METRIC (Mapping EvapoTranspiration at high spatial Resolution with Internalized Calibration) algorithm [30] with Landsat satellite data was applied to map regional distributions of ET. METRIC has attractive features for retrieval of ET distributions over heterogeneous field sites for the following reasons: (1) it consists of physically based image analysis algorithms; (2) the need for atmospheric correction of short wave and thermal information in images is reduced an internal calibration based on the selection of a cold (well-watered crop under full cover) and hot pixel (bare soil without evaporation) in each image; (3) METRIC includes terrain models for solar and thermal radiation calculation; (4) it was used successfully with Landsat images at spatial scales of 30-60 m and MODIS images at spatial scales of 250-1000 m [31-36]; (5) it improves the performance of hydrologic decision support tools compared to their traditional implementations [37].

The METRIC algorithm employs the innovative CIMEC (Calibration using Inverse Modeling at Extreme Conditions) method pioneered in the Surface Energy Balance Algorithms for Land (SEBAL) model to overcome biases in land surface temperature (LST) retrievals and unknown spatial variation in near surface air temperature to estimate sensible heat flux [38]. The CIMEC is an endpoint calibration procedure that identifies pixels with near extreme conditions in the image and estimates appropriate ET values for those pixels [39]. The METRIC/SEBAL approach demonstrated ET accuracies of $\pm 15 \%, 10 \%$, and $\pm 5 \%$ for daily, monthly, and seasonal timescales $[27,40,41]$.

METRIC computes the latent heat flux as the residue of the surface energy balance using

$$
\lambda E=R_{n}-G-H
$$

where $R_{n}$ is the net incoming radiation flux density, $G$ is the ground heat flux density, $H$ is the sensible heat flux density, and $\lambda E$ is the latent heat flux density. The parameter $\lambda$ is the latent heat of vaporization of water, and $E$ is the vapor flux density. Air humidity measurements are not needed because evaporation is computed as a residual of the surface energy balance [41].

METRIC also combines the computation of surface albedo, surface temperature, and vegetation indices from multi spectral satellites such as Landsat. Vegetation indices and LST govern the estimation of soil heat flux according to light interception effects by canopies and vegetation indices. These are used to estimate spatial variability in aerodynamic roughness of landscape variation.

Finally, METRIC leverages the high-quality hourly meteorological measurements to capture impacts of regional advection and changing wind and humidity conditions during a day $[42,43]$. METRIC is unique among energy balance-based approaches in that it uses the reference ET fraction $\left(\mathrm{ET}_{\mathrm{r}} \mathrm{F}\right)$ to interpolate relative ET between satellite image dates. $\mathrm{ET}_{\mathrm{r}} \mathrm{F}$ is the ratio of actual ET of an image pixel to reference ET at a regional weather station, where the reference ET computed via the Penman-Monteith formulation [41] is an index for potential ET. Daily and hourly weather data from the Maricopa weather station of the Arizona Meteorological Network were used. When high quality hourly meteorological data were not available, SEBAL was used instead. Derived ET and ET $_{\mathrm{r}} \mathrm{F}$ images on satellite dates were valuable for outlining spatial extents of ET. ET over an extended period was estimated using these "snapshots" of $\mathrm{ET}_{\mathrm{r}} \mathrm{F}$ by spline interpolation $[30,41]$ of $\mathrm{ET}_{\mathrm{r}} \mathrm{F}$ between satellite image days and multiplying daily $\mathrm{ET}_{\mathrm{r}} \mathrm{F}$ by daily $\mathrm{ET}_{\mathrm{r}}$ from a weather location. Biases induced by the insertion of subregional $\mathrm{ET}_{\mathrm{r}}$ as a divisor in METRIC to produce $\mathrm{ET}_{\mathrm{r}} \mathrm{F}$ were largely self-canceled by the later multiplication of daily $\mathrm{ET}_{\mathrm{r}}$ from the same weather location. The final products for this project were daily ET maps (365 maps per year) for the selected wet years (2001, 2005) and dry year (2002) (Figure 2). 


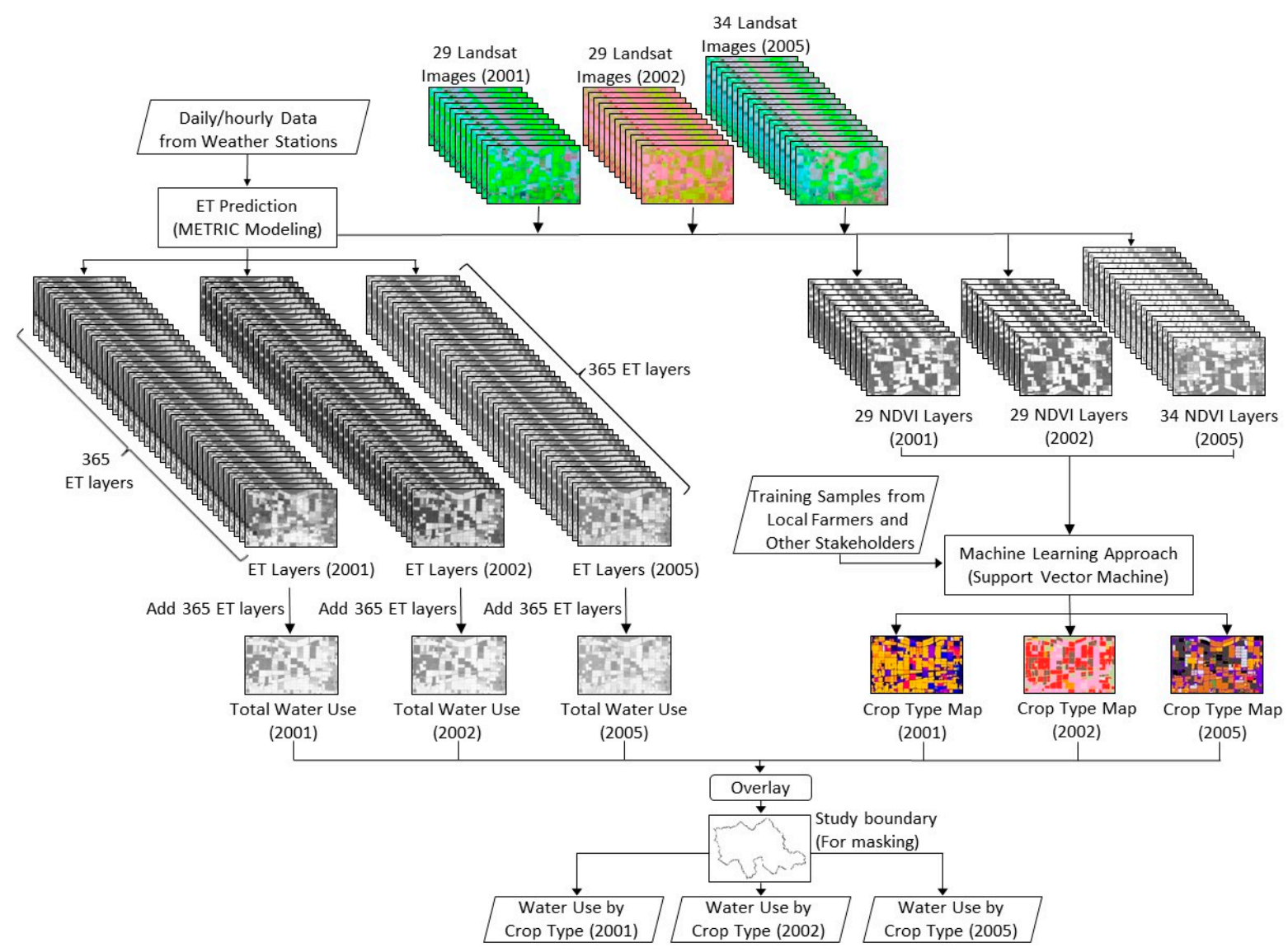

Figure 2. ET modeling and crop identification to quantify crop water use. This diagram demonstrates how ET maps (1095 ET maps) and crop type maps (3 year crop maps) were generated using 92 Landsat scenes, daily ancillary data from weather stations, and reference crop type data to determine consumptive water use by crop.

\subsection{Annual ET and Water Use Data}

Total annual ET was derived by summarizing 365 daily ET map layers. Total annual ET data were aggregated into annual total water use at the farm unit and the irrigation district levels. Water use data were provided by the Arizona Department of Water Resources (ADWR) at two different spatial scales: one at the irrigation district level and the other at the farm unit level. There is a total of 15 irrigation districts in the Phoenix AMA. The irrigation districts, ranked by land area, include Salt River Valley Water Users Association (SRVWUA), Roosevelt Irrigation District (ROOSID), Buckeye Conservation and Drainage District (BUCKEYE), Roosevelt Water Conservation District (RWCD), Maricopa Water District (MWD), Queen Creek Irrigation District (QCID), Arlington Canal Company (ARLINGTON), Tonopah Irrigation District (TONOPAH), Peninsula Ditch and Irrigation District (PENINSULA), Adaman Irrigation Water Delivery District (AIWDD), Saint John's Irrigation District (STJOHNS), San Tan Irrigation District (TANTAN), Chandler Heights Citrus Irrigation District (CHCID), Citrus Heights Ranch (CHTR), and Sun Valley Farms Coop III (SVFIII). According to the data records, SVFIII was inactive in 2001. While the irrigation districts only reported agricultural water use, the ADWR farm unit data have detailed information on both water use and irrigated acres. A farm unit is defined in the Phoenix AMA as one or more farms that are in proximity to each other with similar soil conditions, crops, cropping patterns, and farm management practices. Figure 3 shows that farm units vary in sizes and are located within or outside of irrigation districts. Due to the potential mismatch between the reported irrigation acres by ADWR and the actual acres detected by the satellite imagery, the total water use for each farm unit was recalculated by multiplying water use per irrigation acre and the actual acre. Water use for a total of 
2132 farm units in the Phoenix AMA is reported in 2001. The relationships between total water use and total annual ET were analyzed using simple linear regression.

$33^{\circ} 40^{\prime}, 112^{\circ} 49^{\prime}$

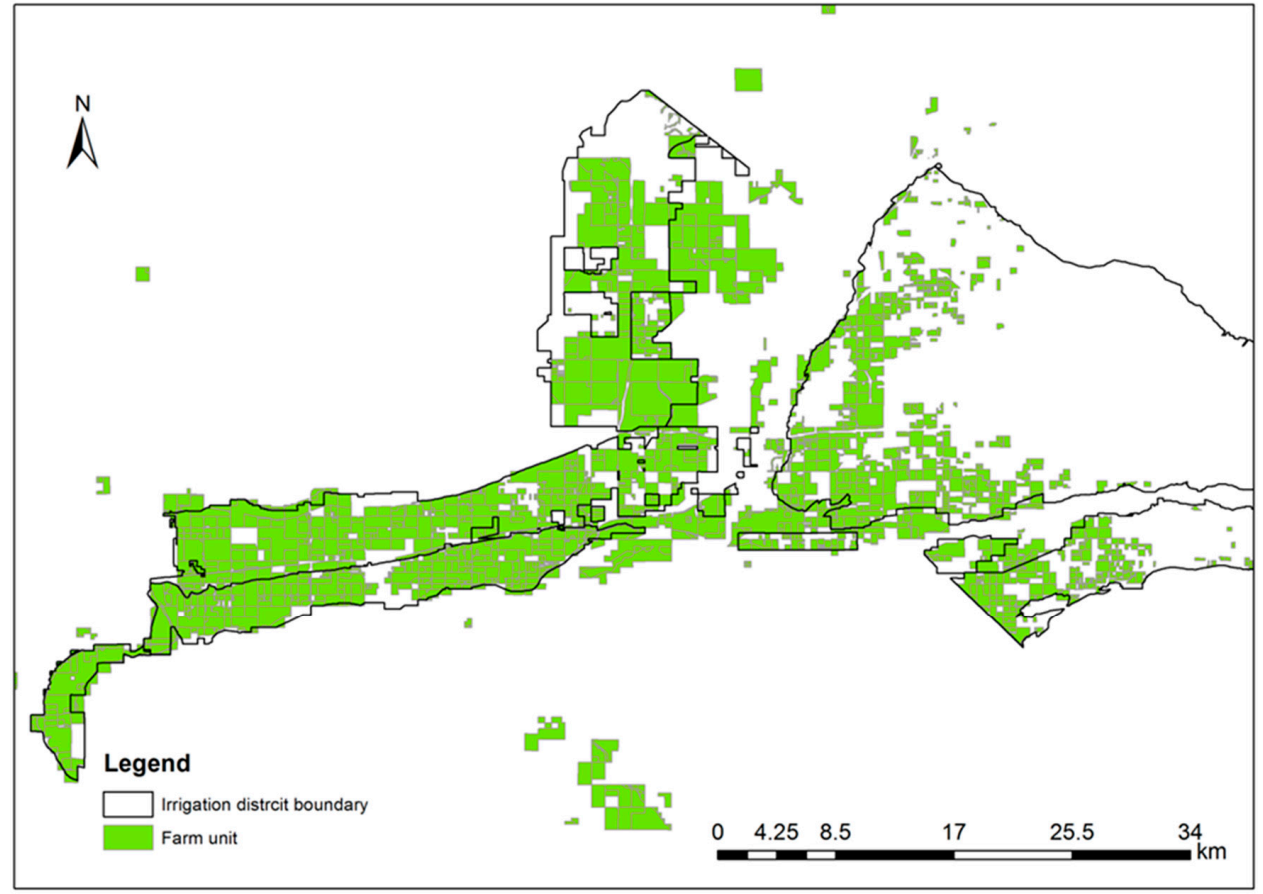

$33^{\circ} 12^{\prime}, 112^{\circ} 2^{\prime}$

Figure 3. Farm units within and around several irrigation districts. The irrigation districts include ARLINGTON, BUCKEYE, ROOSID, MWD, AIWDD, SRVWUA, STJOHNS, and PENINSULA. Note that farm units can be located outside of any irrigation districts.

\subsection{Crop Type Mapping}

We applied the support vector machine (SVM) classifiers to Landsat time-series NDVI (normalized difference vegetation index) data to identify major crop types in our study area. The SVM was effective in differentiating major crop types in the Phoenix AMA area with an overall accuracy of $90 \%$ [44]. The SVM is a non-parametric, machine learning classifier, and one major advantage of an SVM classifier is its good generalization ability to unseen data with a small training dataset [45-47]. Totals of 29, 30, and 26 Landsat scenes (Path 37/Row 37 ) with less than $5 \%$ cloud cover were available for crop type classification for 2001, 2002, and 2005, respectively. Training and validation crop type data came from local growers and USDA Farm Service Agency (FSA). In addition, prior knowledge of cropping practices and crop phenological patterns were used to acquire additional reference data. The prior knowledge came from 15 field visits in 2013 (including collecting individual agricultural field GPS locations, corresponding crop types, and photos and interviewing local farmers, farm managers, and irrigation district managers), 2013 time series NDVI data, along with 2010 Cropland Data Layer (CDL), which allowed us to link what was observed on the ground with the crop phenological patterns shown by the time-series Landsat images. Thirty samples were selected for training, and the rest of the samples (523, 690, and 765) were used for validation for years 2001, 2002, and 2005, respectively. We evaluated the accuracy of the crop type map using overall accuracy, kappa statistics, and producer's and user's accuracies [48]. The 2001, the 2002, and the 2005 crop type maps had overall accuracies of $92 \%, 93 \%$, and $91 \%$. Table 1 shows the error matrix of nine categories with an overall accuracy of $92 \%$ for 2001 crop type map. Because the same image preprocessing and classification procedures described in [44] were used, a repetitive, lengthy description is unnecessary, as readers can refer to [44] for a detailed explanation of SVM as well as 
specific image preprocessing and classification procedures. A layer of Landsat NDVI time series data and its crop type map are presented in Figure 4.

Table 1. Image classification accuracy using 2001 crop type map as an example (Alf = Alfalfa; Cot = Cotton; Cor = Corn; Whe $=$ Wheat; Sor = Sorghum; Pro-Accu = Producer's Accuracy; Usr-Accu = User's Accuracy).

\begin{tabular}{ccccccccccccc}
\hline \multicolumn{10}{c}{ Reference } \\
\hline Classified & Alf & Cot & Cor & Whe & Alf-Cot & Cor-Alf & Whe-Sor & Whe-Cot & O-Crops & Total & Pro-Accu & Usr-Accu \\
\hline Alf & 114 & 0 & 0 & 0 & 0 & 0 & 0 & 0 & 6 & 120 & 95 & 95 \\
Cot & 0 & 109 & 0 & 0 & 0 & 0 & 0 & 0 & 1 & 110 & 100 & 99 \\
Cor & 0 & 0 & 32 & 0 & 0 & 0 & 0 & 0 & 7 & 39 & 94 & 82 \\
Whe & 1 & 0 & 2 & 42 & 0 & 0 & 2 & 0 & 2 & 49 & 100 & 86 \\
Alf-Cot & 1 & 0 & 0 & 0 & 25 & 0 & 0 & 0 & 4 & 30 & 100 & 83 \\
Cor-Alf & 0 & 0 & 0 & 0 & 0 & 28 & 0 & 0 & 2 & 30 & 100 & 93 \\
Whe-Sor & 1 & 0 & 0 & 0 & 0 & 0 & 27 & 0 & 2 & 30 & 84 & 90 \\
Whe-Cot & 0 & 0 & 0 & 0 & 0 & 0 & 3 & 26 & 3 & 32 & 100 & 81 \\
O-crops & 3 & 0 & 0 & 0 & 0 & 0 & 0 & 0 & 80 & 83 & 75 \\
\hline Total & 120 & 109 & 34 & 42 & 25 & 28 & 32 & 26 & 107 & 523 & 96 \\
\hline
\end{tabular}

Overall Acuracy $=92 \%$. Kappa Coefficient $=90 \%$.

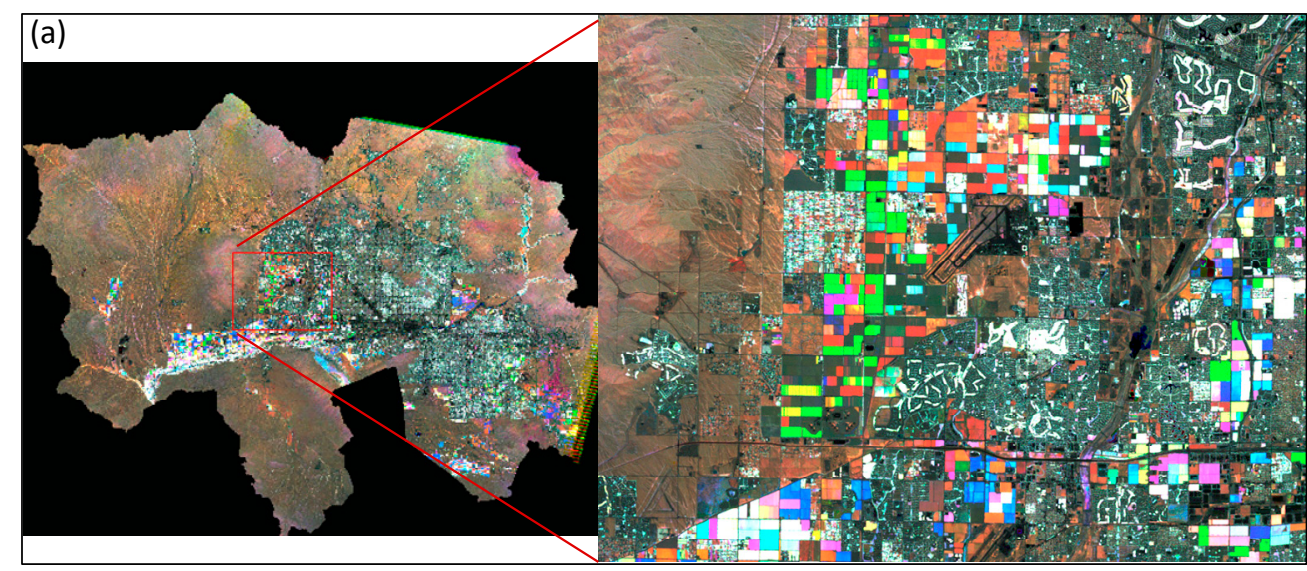
(b) $\quad 33^{\circ} 29^{\prime}, 112^{\circ} 44^{\prime}$

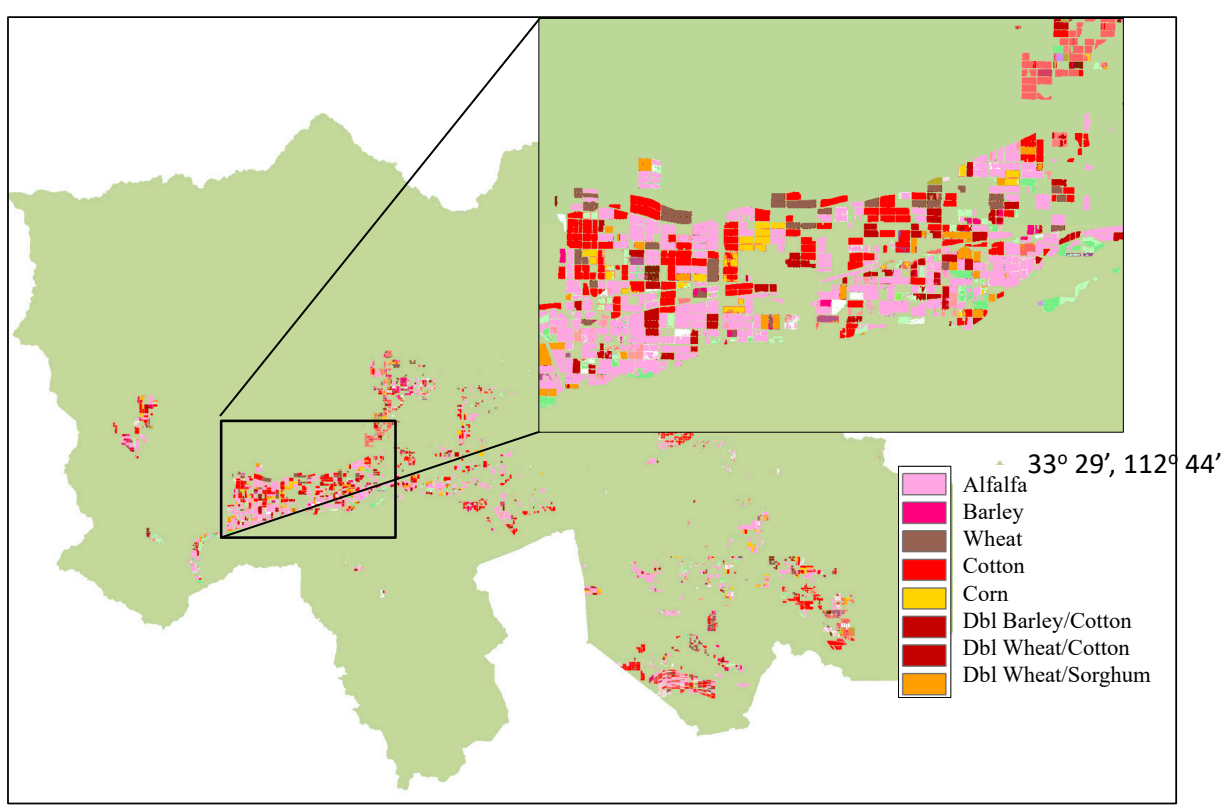

Figure 4. Landsat NDVI time series data and its crop type map. In total, 29 NDVI layers in 2001 (a) were used to generate its crop type map (b) using the support vector machine (SVM) classifiers. 


\subsection{Spatial Data Processing}

Agricultural water use varies from field to field and from irrigation district to irrigation district due to differences in soil properties, water quality, and management practices. Spatial variation of total annual ET was analyzed at both AMA and irrigation levels. ET values of non-cropped areas were first assigned as no data so that they could be excluded from the calculation of mean value. The following data products were calculated using a zonal statistic function in the ArcMap software (version 10.7.1): (1) mean ET for each irrigation district; (2) mean ET for each crop type for the entire study area; and (3) average ET for each crop type for each irrigation district. The crop type map (Figure 5) was used to guide the calculation of average ET for each crop type.

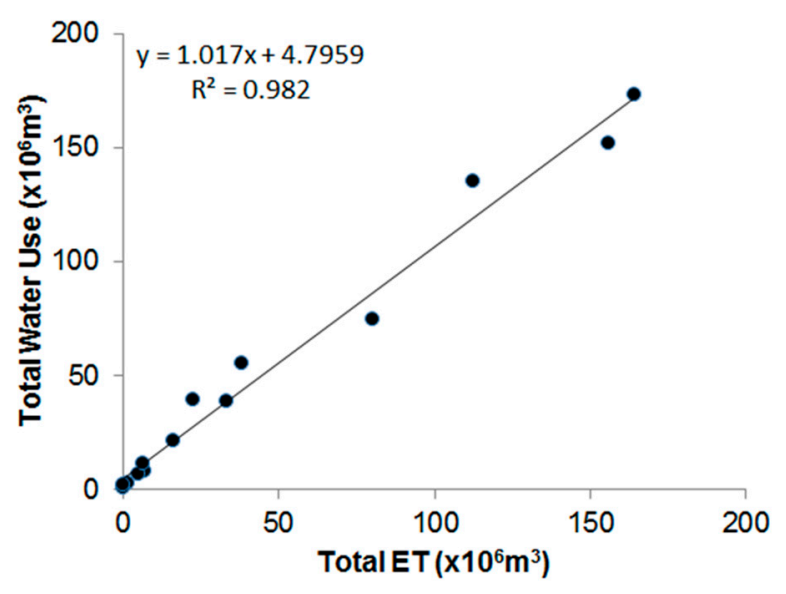

(a)

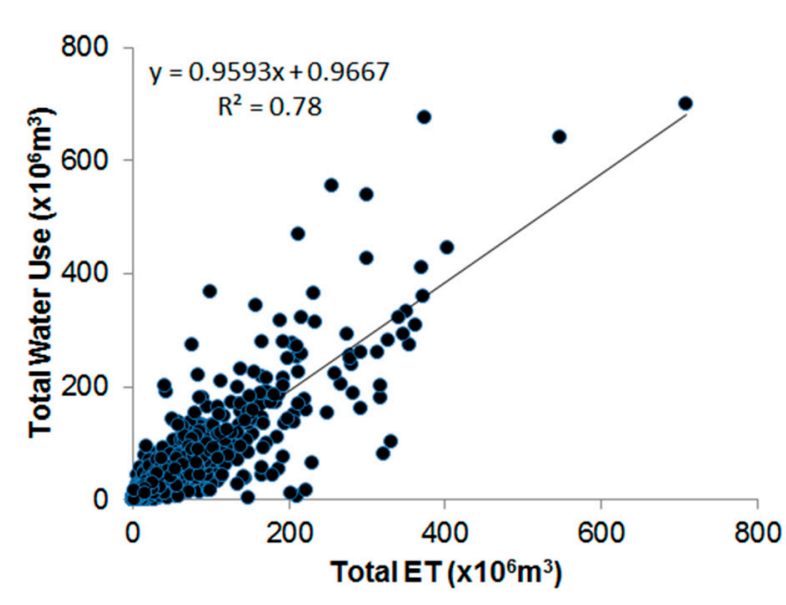

(b)

Figure 5. Comparison between total annual ET and total water use. (a) Irrigation district level; (b) farm unit level.

\section{Results and Discussion}

\subsection{Relationships between Estimated ET and Water Use Data}

Total annual ET was well correlated with total water use with an $R^{2}$ of 0.98 at the irrigation district level and with an $R^{2}$ of 0.78 at the farm unit level (Figure 5). The correlations between the estimated ET and the reported agricultural water use data demonstrate the suitability of using satellite derived ET data for agricultural water use prediction. The correlation was higher at the irrigation district level than at the farm unit level, probably because errors tended to be minimized among farm units when the ET data were aggregated to a large spatial scale. The application of satellite derived ET for estimation of irrigation water consumption was based on the assumption of a correlation between the ET and the total water applied. However, due to variations in soil conditions, water quality, farm management practices, and microclimate, water use efficiency can vary from one farm unit to another. For example, water use efficiency could be lower in areas with sandy soils because of low water holding capacity as compared to clay soils. As a result, for the same amount of water applied, more water is drained through the sandy soils. Therefore, the relationships between ET estimates and total water use could slightly vary from place to place. We further grouped farm units by irrigation district and examined the relationships within each irrigation district.

Figure 6 shows scatter plots of the farm unit total water use versus ET estimation for irrigation districts that have more than ten farm units. In general, correlations between total water use and ET estimation were higher compared to the $R^{2}$ of 0.78 when constraining the spatial extent within an individual irrigation district, which could be largely due to the same source of water and relatively similar type of soils for farms in the same irrigation district, especially for those small districts in area. The highest correlation was found in ARLINGTON $\left(R^{2}=0.94\right)$ and TONOPAH $\left(R^{2}=0.92\right)$, while STJOHNS and BUCKEYE had 
the lowest correlations (Figure 6). These results suggest that the high correlations between water use and ET estimation derived from the individual irrigation district have better capability to predict farm unit water use. Samples above and far away from the 1:1 line (i.e., the dotted line) indicate overapplication of water or low water use efficiency (Figure 6). Overapplication cases occurred the most in BUCKEYE, where soil salinity issues were worse than other irrigation districts (Figure 6). The relatively low $R^{2}$ values observed in several irrigation districts indicate the existence of low water use efficiency farms, and further assessment of those farms is required. The irrigation districts with relatively low $R^{2}$ values demonstrate that predicted ET values were slightly lower than actual water use. However, the relationships between ET estimated by the METRIC model and actual water use were strong in general with $R^{2}$ values above 0.72 for all the irrigation districts except STJOHNS $\left(R^{2}=0.5\right)$.
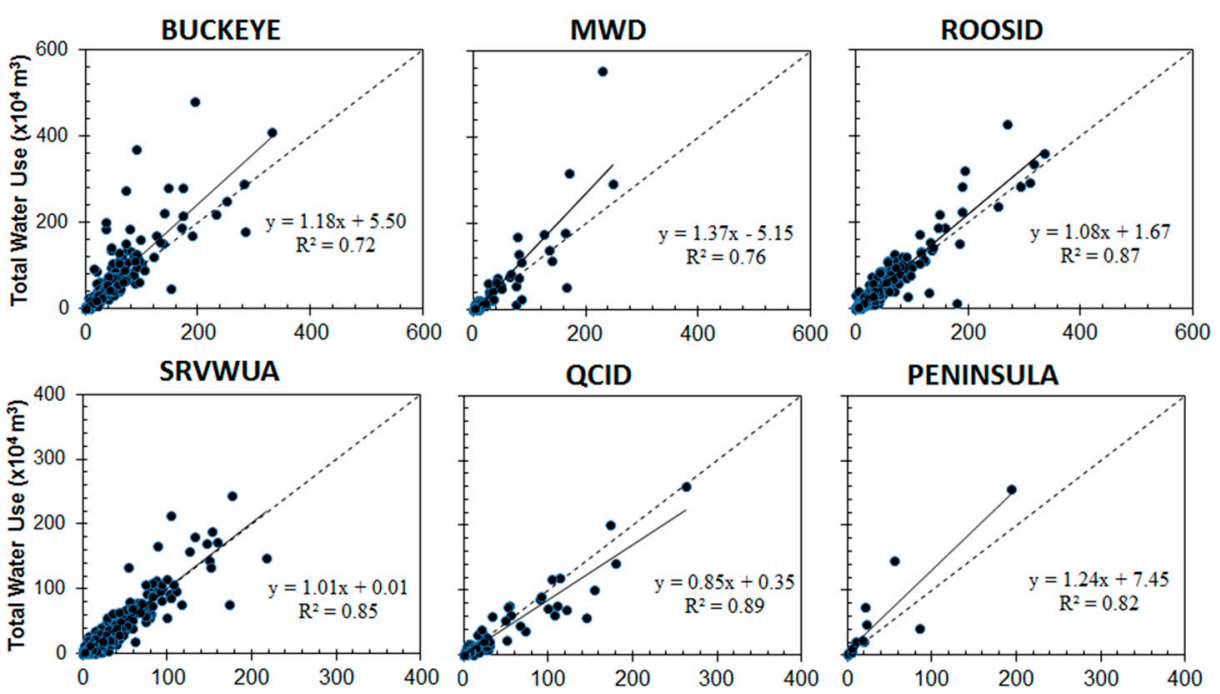

PENINSULA
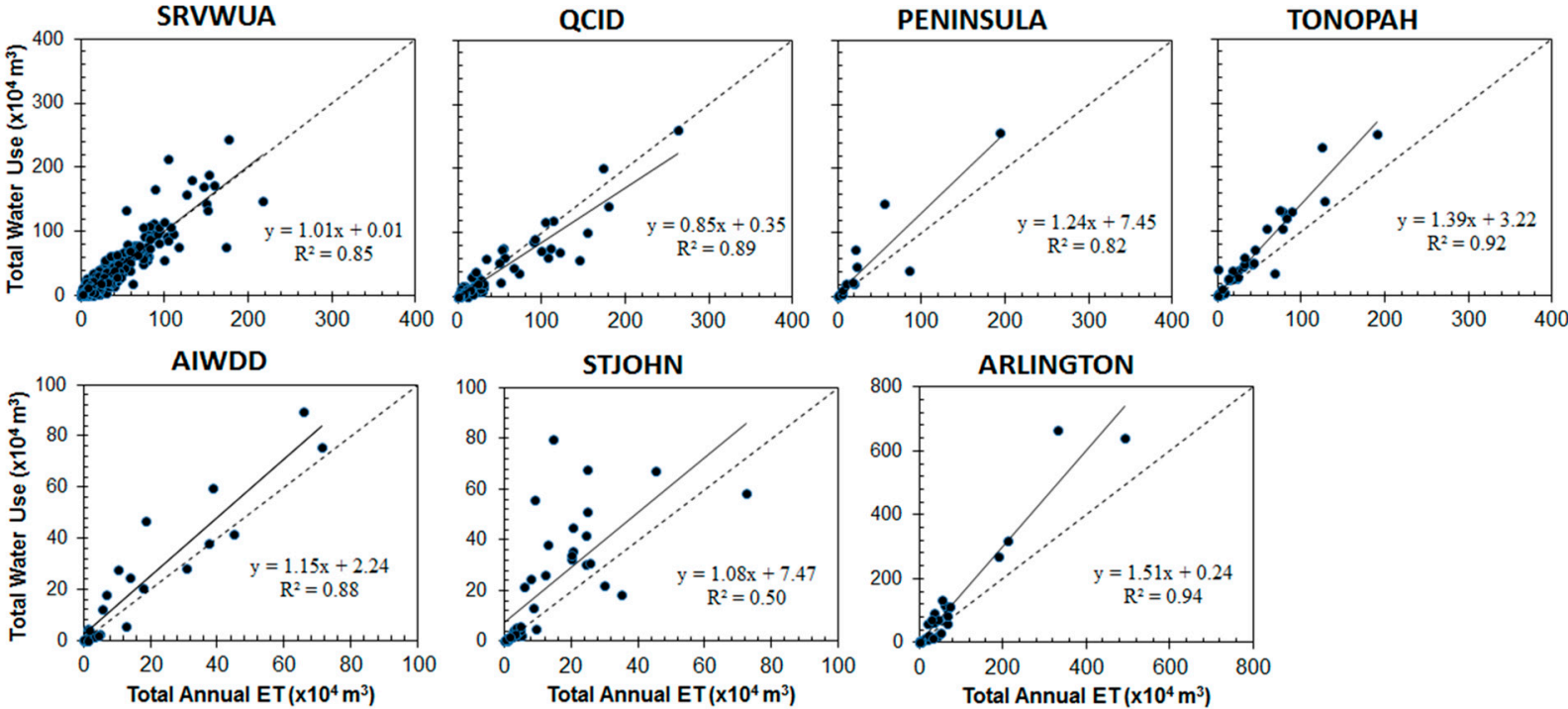

Figure 6. Comparison between total annual ET and total water use. The analysis was performed at the farm unit level for each irrigation district.

Studies compared METRIC-derived ET data to those measured by precision lysimeters and found differences as low as $4 \%$ for seasonal ET totals [30], thus further confirming the reliability of this method. Based on a pilot study in Idaho, research found that, for monitoring agricultural water use from irrigation wells, ET data are not only more reliable but also more cost-effective than power consumption data by a factor of greater than five to one [49].

\subsection{Variation of Water Consumed across Crops}

Table 2 shows the water consumed by crops using the ET calculation method outlined in the previous section. As shown in this table, in terms of single crop types, alfalfa consumed the most water (averaged over wet and dry years) followed by cotton; barley used the least amount of water. It is interesting to note that alfalfa used more water than even double cropping mixes, such as wheat-sorghum and wheat-cotton. The variation 
in water intensities among the crops grown in the region is quite striking, with alfalfa consuming 3.2 times and cotton consuming 2.2 times the water used by barley.

Table 2. Mean water consumed by crop type in the PHX AMA in dry and wet years.

\begin{tabular}{ccccc}
\hline & $\begin{array}{c}\text { Mean Water Use } \\
\text { (Dry Year) } \\
\mathbf{( m m )}\end{array}$ & $\begin{array}{c}\text { Mean Water Use } \\
\text { (Wet Year) } \\
(\mathbf{m m})\end{array}$ & $\begin{array}{c}\text { Difference } \\
\mathbf{( m m})\end{array}$ & $\begin{array}{c}\text { Water Use } \\
\text { (Mean Dry and Wet Year) } \\
(\mathbf{m m})\end{array}$ \\
\hline Alfalfa & 1616.16 & 1536.05 & 80.11 & 1576.11 \\
Barley & 591.56 & 405.56 & 186.00 & 498.56 \\
Corn & 867.41 & 817.79 & 49.62 & 842.60 \\
Cotton & 1054.80 & 1139.04 & -84.24 & 1096.92 \\
Wheat & 737.75 & 643.75 & 94.00 & 690.75 \\
Dbl. Wheat/Cotton & 1357.89 & 1388.90 & -31.01 & 1373.39 \\
Dbl. Wheat/Sorghum & 1435.00 & 1381.28 & 53.72 & 1408.14 \\
\hline
\end{tabular}

Table 3 compares the water consumption rates that were obtained through the ET calculations for Maricopa County with the water use rates reported for the state of Arizona in the U.S. Department of Agriculture's Farm and Ranch Irrigation Survey [18]. As noted in the survey documentation, "most water used for irrigation is not metered or measured accurately. The quantity of water data is on the basis of best estimates provided by irrigators" [18]. Thus, the calculated ET rates were expected to be a more reliable measure of the consumptive use of water. The water use rates reported in the survey included both consumptive and non-consumptive uses of water and thus were expected to be somewhat higher than the ET rates estimated. This was consistent with what was found in the study (see Table 3) with the difference between the two estimates being highest for wheat. This could be partly because, when leaf area index is low, soil evaporation is a significant part of total ET, and, on average, soil evaporation under a wheat canopy accounted for $30 \%$ of total evaporation [50].

Table 3. Comparison of water application rates in USDA survey with ET rates. (Source: USDA data were taken from Farm and Irrigation Survey for Arizona (USDA, 2003)).

\begin{tabular}{cccccc}
\hline \multirow{2}{*}{ Crop Type } & $\begin{array}{c}\text { USDA (All of } \\
\text { Arizona) } \\
(\mathbf{m m})\end{array}$ & Average & Our Study (Maricopa County) & \multicolumn{2}{c}{$\begin{array}{c}\text { Difference: USDA } \\
\text { and This Study }\end{array}$} \\
\cline { 2 - 5 } & 1889.76 & 1575.82 & 1536.19 & 1615.44 & 313.94 \\
\hline Alfalfa & 1463.04 & 1097.28 & 1139.95 & 1054.61 & 365.76 \\
\hline Cotton & 1097.28 & 664.46 & 609.60 & 722.38 & 432.82 \\
\hline Wheat & 1097.28 & 853.44 & 829.06 & 874.78 & 243.84 \\
\hline Corn & & & & &
\end{tabular}

Table 2 shows that, for each crop type, water consumption was higher in dry years versus wet years, except for cotton as a single crop or double cropped with wheat. For reasons listed in the previous section, potential ET was expected to be higher in dry years, and actual ET was also expected to be higher in dry years as long as water availability was not a constraint. To understand the anomalous pattern of water use for cotton, several farmers and irrigation district managers were consulted. Based on their experience, they suggested that this unusual pattern could be explained by the fact that planting and harvesting of cotton in wet years often gets delayed. Normally, cotton is planted from March to June and harvested from September to January in the region under study [51]. Common planting and harvesting dates for some example crops are presented in Figure 7. If precipitation occurs during the planting time for cotton (e.g., spring showers around March/April), farmers generally delay planting, which implies that cotton will mature 
during an even hotter period in the year and thus require more water [52]. Furthermore, farmers reported that, if precipitation occurs in the early crop growth stage, they often end up replanting, which requires additional irrigations [52]. The reason why this anomalous pattern was observed only for cotton (grown as single crop or double crop) was because it was the only crop in the region that was planted in spring (thus vulnerable to timing and intensity of spring showers) and grew through the summer to be harvested in fall [44,51]. Another study pointed out that delays in planting cotton due to drought or excess rainfall can lead to loss of growing days or stand failure, and a June drought can lead to crop establishment failure [53]. To secure stand establishment and reduce risk, growers understand the importance of sufficient water. The cotton bolls need sufficient time to open and grow, and they critically rely on temperature and rain.

\begin{tabular}{llllllll} 
& Jan Feb Mar Apr May Jun Jul Aug Sep Oct Nov Dec \\
\hline Barley & & & & & & \\
\hline Wheat & & & & & & \\
\hline Potatoes & & & & & & \\
\hline Corn & & & & & & \\
\hline Cotton & & & & & \\
\hline Sorghum & & & & & \\
\hline Alfalfa & & & & & & \\
\hline
\end{tabular}

\section{Planting Harvest $\quad$ Planting or harvest}

Figure 7. Common planting and harvesting dates for some crops grown in the region (USDA-NASS, 2004).

Unraveling this anomalous result with respect to water use for cotton in dry versus wet years helps us understand the complexity of farmers' decision making under uncertainty. The ET data across dry and wet years show that the rather simplistic understanding of irrigated farming that leads people to assume that less irrigation water would be used when there is excessive precipitation is not necessarily accurate. What matters is the timing of the precipitation with respect to water needs of the crop in its different growth stages. As a farmer observed during our interview, "in irrigated agriculture, rain is not always welcome. Rain at the wrong time, can mess things up."

\subsection{Variation across Irrigation Districts}

Figure $8 \mathrm{a}-\mathrm{g}$ show that the water consumption patterns observed at the county level held true in general when the irrigation district level was disaggregated. In almost all irrigation districts, all crop types (except cotton) consumed more water in dry years than in wet years. Cotton's water consumption was observed to be higher in dry years than wet years in only one district (MWD) (see Figure 8d). 

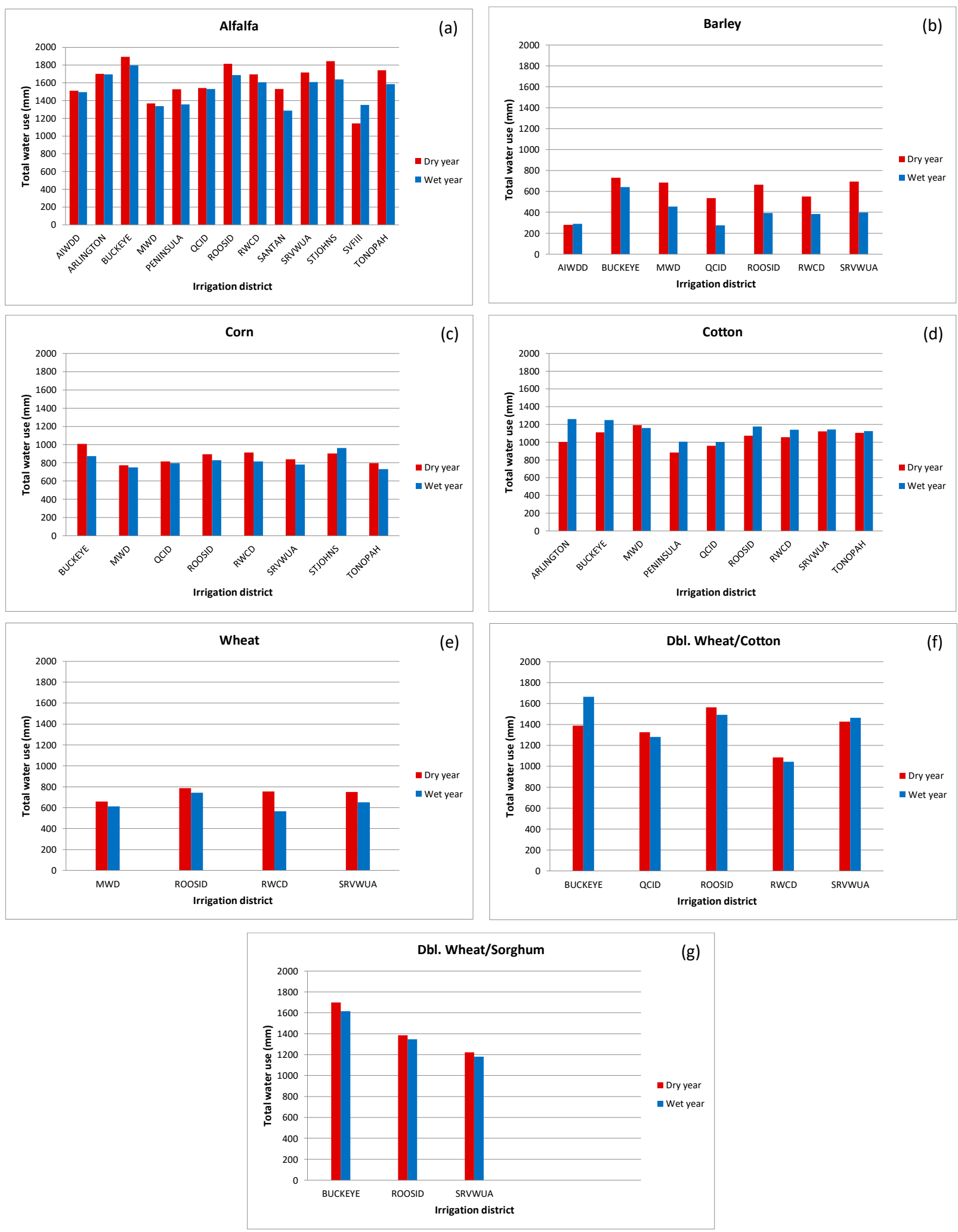

Figure 8. Water consumed by different crops across irrigation districts. (a) SVFIII water consumed for alfalfa was higher in a wet year than a dry year (an exception to the rest); (b) AIWDD water consumed for Barley was higher in a wet year than a dry year (an exception to the rest); (c) St. Johns water consumed for corn was higher in a wet year than a dry year (an exception to the rest); (d). MWD water consumed for cotton was higher in a dry year than wet year (an exception to the rest); (e) Water consumed for wheat was higher in dry year than wet year for all districts (i.e., SRVWUA, ROOSID, RWCD, MWD); (f) Water consumed for Dbl. Wheat/Cotton was higher in dry year than wet year for QCID, ROOSID, and RWD (an exception to the rest); (g) Water consumed for Dbl. Wheat/Sorghum was higher in dry year thanwet year for all districts (i.e., BUCKEYE, ROOSID, SRVWUA). 
The anomalous pattern observed in the case of cotton, with water consumption higher in wet years than dry years, was also observed when cotton was double cropped with wheat, but this pattern was less consistent across irrigation districts. On average, water use for wheat/cotton double cropping was slightly higher in wet years than in dry years, but in three out of five irrigation districts, the pattern was reversed (see Figure 8). Research reported that a slight or acute soil water deficit considerably reduced ET, which predominantly depended on irrigation water [54]. Since water use for most crop types in almost all irrigation districts was higher in dry years than in wet years (see Table 2 above), it was concluded that irrigated agriculture consumed more water in dry years than in wet years.

An analysis of variance (ANOVA) test was performed, as shown in Table 4, and it was found that variations in water consumption between dry and wet years were statistically significant, controlling for crop types, crop irrigated years, and irrigation districts.

Table 4. Statistical significance test of difference in crop water use between dry and wet years.

\begin{tabular}{|c|c|c|c|c|c|}
\hline \multirow{2}{*}{\begin{tabular}{l} 
Number of \\
Observations $=98$ \\
Root MSE $=101.781$ \\
\multicolumn{1}{c}{ Source }
\end{tabular}} & \multicolumn{5}{|c|}{$\begin{array}{l}\text { R-Squared }=0.9530 \\
\text { Adjusted R-Squared }=0.9415\end{array}$} \\
\hline & Partial SS & $\mathrm{df}$ & MS & $\mathbf{F}$ & Prob $>$ F \\
\hline Model & $16,382,967.60$ & 19 & $862,261.45$ & 83.24 & 0.0000 \\
\hline Crop type & $13,644,609.80$ & 6 & $2,274,101.64$ & 219.52 & 0.0000 \\
\hline Irrigation District & $1,058,549.38$ & 12 & $88,212.45$ & 8.52 & 0.0000 \\
\hline Year & $108,394.45$ & 1 & $108,394.45$ & 10.46 & 0.0018 \\
\hline Residual & $808,028.94$ & 78 & 359.35 & & \\
\hline Total & $17,190,996.50$ & 97 & $177,226.77$ & & \\
\hline
\end{tabular}

\subsection{Potential for Water Savings through Appropriate Choice of Crops and Farming Practices}

Notably, farming practices such as double cropping (e.g., barley/cotton) in a single year consumed significantly less water than the total water consumed by each crop grown as a single crop per year in two different years or in two different farm areas. For example, barley / cotton double cropping consumed $1417 \mathrm{~L} / \mathrm{m}^{2}$, whereas a single crop of barley and cotton in two different years or two different areas consumed $1837 \mathrm{~L} / \mathrm{m}^{2}$ (Table 5). Since barley/cotton double cropping was not detected in 2001 and 2005, this result was based on what was observed in 2002, which was a dry year. As seen in Table 5, if barley and cotton were grown sequentially as a double cropping option in the same area used for the two single crops in 2002, then 36,906 million liters (or $22.87 \%$ of water consumed) could have been saved. In addition to water savings, if barley and cotton were double cropped instead of grown as a single crop using the total area $\left(87,849,978 \mathrm{~m}^{2}\right)$, the barley yield could have been nine times higher than the original single crop yield $\left(87,849,978 \mathrm{~m}^{2}\right.$ vs. $\left.9,763,209 \mathrm{~m}^{2}\right)$, and the cotton yield could have increased by $12.50 \%\left(87,849,978 \mathrm{~m}^{2}\right.$ vs. $\left.78,086,769 \mathrm{~m}^{2}\right)$ over the original single crop yield given the same biophysical and weather conditions (e.g., soil type, rainfall, amount of irrigated water, wind speed and direction, sunlight, quality of crop). Water savings and yield could even have been much higher if multiple cropping practices had been considered. 
Table 5. Difference in water consumption between barley/cotton double-cropping and barley and cotton as single crops (2002 data).

\begin{tabular}{|c|c|c|c|c|c|}
\hline & Barley & Cotton & $\begin{array}{l}\text { Barley \& Cotton } \\
\text { as Single Crops }\end{array}$ & $\begin{array}{c}\text { Double Cropping } \\
\text { Barley/Cotton }\end{array}$ & \\
\hline $\begin{array}{l}\text { Water Use } \\
\left(\text { liter } / \mathrm{m}^{2}\right)\end{array}$ & 746 & 1090 & 1837 & 1417 & Water Saving \\
\hline Crop area $\left(\mathrm{m}^{2}\right)$ & $9,763,209$ & $78,086,769$ & $87,849,978$ & $9,223,208$ & Double cropping \\
\hline $\begin{array}{l}\text { Water use (Million } \\
\text { Liters) }\end{array}$ & 7288 & 85,142 & 161,365 & 124,459 & Barley \& Cotton \\
\hline \multicolumn{5}{|c|}{ Water Saving by growing double cropping Barley/Cotton (liter $/ \mathrm{m}^{2}$ ) } & 420 \\
\hline \multicolumn{5}{|c|}{ Water saving by growing double cropping Barley/Cotton (\%) } & $22.87 \%$ \\
\hline \multicolumn{5}{|c|}{ Water Saving (million liter) using total area $\left(87,849,978 \mathrm{~m}^{2}\right)$ of Barley \& Cotton as single crops } & 36,906 \\
\hline
\end{tabular}

Studies from other regions of the US also provide support for our results on the potential benefits of double cropping practices. For example, one study in Southern Pennsylvania found that the addition of a small grain silage crop to a main crop of corn or soybean did not affect main crop silage yields and therefore added to annual silage yields without negative effects on the water balance [55]. Other studies found that winter crop improved soil water conditions by increasing organic matter content and improving soil structure, resulting in increased infiltration of rainfall, increased water holding capacity, and higher soil water contents $[56,57]$. Higher organic matter content increases absorptive surface areas in the soil, thus improving soil water holding capacity and soil water storage [57]. Fallow systems in California were found to cause more soil water loss than double cropped systems [58], and winter cover through a second crop was associated with improved soil water storage for the subsequent crop. These benefits associated with double cropping were further confirmed through our discussions with farmers in the study region who have been double cropping wheat with cotton for several years. One innovative farmer reported combining minimum till with a 6 year crop rotation cycle for further increases in yields and water savings [59].

In addition to the choice of appropriate farming practices, there is also the possibility of significant water savings through appropriate choice of crops. Among the crops grown in the region, alfalfa consumed the highest volume of water per acre $\left(1576 \mathrm{~L} / \mathrm{m}^{2}\right)$, followed by cotton $\left(1097 \mathrm{~L} / \mathrm{m}^{2}\right)$ (Table 6). Water consumption in corn $\left(843 \mathrm{~L} / \mathrm{m}^{2}\right)$ and wheat $\left(691 \mathrm{~L} / \mathrm{m}^{2}\right)$ ranked third and fourth, respectively. Barley consumed the lowest amount of water (499 $\mathrm{L} / \mathrm{m}^{2}$ ), which was about $32 \%$ of water use in alfalfa and $45 \%$ in cotton. Water use per square meter for wheat was about $44 \%$ of the water use rate of alfalfa and $63 \%$ of cotton. These numbers point to the wide variation in water consumption of crops grown in this region and point to the possibility of significant savings through shifts in crop choice. A study reported wheat-vegetables rotations not only reduced absolute consumptive use of water but also improved economic water productivity [60]. It was found that wheat-vegetable rotations reduced per acre water use by $24 \%$ to $56 \%$ compared to other cropping patterns. The shift to crop rotations also significantly improved the dollar value of crop production per acre-foot of water consumed (economic water productivity). The same study reported that wheat-vegetable rotations increased economic water productivity 9 to 21 times in comparison to older cropping practices. It was noted that, over the last 30 years, local farmers in Arizona have greatly increased the amount of grain they can produce per cubic meter of water applied [60]. 
Table 6. Difference in water consumption between dry and wet years by crop type $(\mathrm{Al}=\mathrm{Alfalfa} ; \mathrm{Br}=\mathrm{Barley} ; \mathrm{Cn}=\mathrm{Corn}$; $\mathrm{Ct}=$ Cotton; $\mathrm{Wh}=$ Wheat; $\mathrm{So}=$ Sorghum).

\begin{tabular}{|c|c|c|c|c|c|c|c|c|c|}
\hline & Liter per $\mathbf{m}^{2}$ & $\begin{array}{c}\text { Average } \\
\text { Liter per } \mathbf{m}^{2}\end{array}$ & $\begin{array}{c}\text { Litre/m² } \\
\text { Difference } \\
\text { between } \\
\text { Dry and } \\
\text { Wet }\end{array}$ & $\begin{array}{c}\text { Increase or } \\
\text { Decrease } \\
(\%)\end{array}$ & $\begin{array}{c}\text { Total Area } \\
\left(\mathrm{m}^{2}\right)\end{array}$ & $\begin{array}{c}\text { Total } \\
\text { Water } \\
\text { Consumed } \\
\text { (Million } \\
\text { Liters) }\end{array}$ & $\begin{array}{c}\text { Difference } \\
\text { between } \\
\text { Dry and } \\
\text { Wet } \\
\text { (Million } \\
\text { Liters) }\end{array}$ & $\begin{array}{l}\text { Average } \\
\text { Water } \\
\text { Consumed } \\
\text { per Year } \\
\text { (Million } \\
\text { Liters) }\end{array}$ & $\begin{array}{c}\text { Water } \\
\text { Consumed } \\
\text { by Crop } \\
\text { Type (\%) }\end{array}$ \\
\hline $\begin{array}{c}\mathrm{Al} \\
\text { (Dry) }\end{array}$ & 1616 & 1576 & 80 & 5.22 & $124,706,810$ & 201,546 & 20,281 & 191,406 & $56.81 \%$ \\
\hline $\begin{array}{c}\mathrm{Al} \\
\text { (Wet) }\end{array}$ & 1536 & & & & $118,007,204$ & 181,265 & & & \\
\hline $\begin{array}{c}\mathrm{Br} \\
\text { (Dry) }\end{array}$ & 592 & 499 & 186 & 45.86 & $9,763,209$ & 5776 & 5016 & 3268 & $0.97 \%$ \\
\hline $\begin{array}{c}\mathrm{Br} \\
\text { (Wet) }\end{array}$ & 406 & & & & $1,873,802$ & 760 & & & \\
\hline $\begin{array}{l}\text { Cn } \\
\text { (Dry) }\end{array}$ & 867 & 843 & 50 & 6.07 & $29,567,726$ & 25,647 & -2646 & 26,971 & $8.01 \%$ \\
\hline $\begin{array}{c}\text { Cn } \\
\text { (Wet) }\end{array}$ & 818 & & & & $34,597,831$ & 28,294 & & & \\
\hline $\begin{array}{c}\mathrm{Ct} \\
\text { (Dry) }\end{array}$ & 1055 & 1097 & -84 & -7.40 & $78,086,769$ & 82,366 & -6143 & 85,438 & $25.36 \%$ \\
\hline $\begin{array}{c}\mathrm{Ct} \\
\text { (Wet) }\end{array}$ & 1139 & & & & $77,705,169$ & 88,509 & & & \\
\hline $\begin{array}{l}\text { Wh } \\
\text { (Dry) }\end{array}$ & 738 & 691 & 94 & 14.60 & $6,374,706$ & 4703 & $-13,135$ & 11,271 & $3.35 \%$ \\
\hline $\begin{array}{l}\text { Wh } \\
\text { (Wet) }\end{array}$ & 644 & & & & $27,710,124$ & 17,838 & & & \\
\hline $\begin{array}{l}\text { Wh/Ct } \\
\text { (Dry) }\end{array}$ & 1358 & 1373 & -31 & -2.23 & $9,223,208$ & 12,524 & 8890 & 8079 & $2.40 \%$ \\
\hline $\begin{array}{l}\text { Wh/Ct } \\
\text { (Wet) }\end{array}$ & 1389 & & & & $2,616,302$ & 3634 & & & \\
\hline $\begin{array}{l}\text { Wh/So } \\
\text { (Dry) }\end{array}$ & 1435 & 1408 & 54 & 3.89 & $3,411,003$ & 4895 & $-11,183$ & 10,486 & $3.11 \%$ \\
\hline $\begin{array}{l}\text { Wh/So } \\
\text { (Wet) }\end{array}$ & 1381 & & & & $11,639,710$ & 16,078 & & & \\
\hline
\end{tabular}

The discussion above was based on water consumption averaged over dry and wet years. Next, how much water consumption varied between dry and wet years for any given crop was examined. This may be an indication of the extent of adaptability of a single crop to climate conditions. Here, it is worth noting that, although barley had the lowest water consumption among all crop types, the difference between its dry year and wet year water consumption was the highest in percentage terms. As shown in Table 6, its ET was $186 \mathrm{~L} / \mathrm{m}^{2}$ more in a dry year compared to a wet year. Despite this higher ET in dry years, barley still maintained its status as the lowest water consumption crop. The second highest difference in water consumption between dry and wet years was observed for wheat $\left(94 \mathrm{~L} / \mathrm{m}^{2}\right)$, followed by alfalfa $\left(80 \mathrm{~L} / \mathrm{m}^{2}\right.$ more) and corn $\left(50 \mathrm{~L} / \mathrm{m}^{2}\right.$ more). As observed earlier, cotton was the only crop whose water consumption in dry years was observed to be lower than in wet years. For all other crops, higher ET in dry years implies that farmers and irrigation managers need to plan for higher water deliveries during dry years when, on the contrary, there is greater pressure for water conservation given lower water availability and higher competition for water.

The total area coverage for each crop in dry years (e.g., 2002) was used as a consistent figure by which to determine how much water could have been saved if the same crop were grown with the same area coverage in a wet year. For example, we used $124,706,810 \mathrm{~m}^{2}$ for alfalfa in both a dry year and a wet year to calculate water savings for wet years since the total alfalfa grown in 2002 (i.e., a dry year) was 124,706,810 $\mathrm{m}^{2}$ (Table 7). In this calculation, wheat/cotton double cropping was not used because they used more water in wet years. In a wet year, 9990 million liters could have been saved with alfalfa if the farmland area 
was the same (i.e., 124,706,810 $\mathrm{m}^{2}$ ) for both dry and wet years (Table 7). The second highest water saving crop in a wet year as well as the second highest water use in a dry year was barley (1816 million liters), followed by corn (1467 million liters), wheat (599 million liters), and wheat/sorghum (183 million liters). This shows how much more water was used in a dry year using the same area coverage of each crop type grown in the Phoenix AMA area by dry and wet years.

Table 7. Water saving by crops in wet years using the same crop area in both dry and wet years $(\mathrm{Al}=$ Alfalfa; $\mathrm{Br}=$ Barley; $\mathrm{Cn}=\mathrm{Corn} ; \mathrm{Ct}=$ Cotton; $\mathrm{Wh}=$ Wheat; So $=$ Sorghum $)$.

\begin{tabular}{ccccc}
\hline $\begin{array}{c}\text { Crop Type } \\
\text { per Year }\end{array}$ & $\begin{array}{c}\text { Water } \\
\text { Consumed } \\
\left(\mathbf{L i t e r}_{\mathbf{m}} \mathbf{2}\right)\end{array}$ & $\begin{array}{c}\text { Dry Year } \\
\text { Area } \\
\mathbf{( m}^{\mathbf{2}} \mathbf{)}\end{array}$ & $\begin{array}{c}\text { Water } \\
\text { Consumed } \\
\text { (Million Liters) }\end{array}$ & $\begin{array}{c}\text { More Water } \\
\text { Consumed } \\
\text { in Dry Year } \\
\text { (Million Liters) }\end{array}$ \\
\hline Al (Dry) & 1616 & $124,706,810$ & 201,546 & 9990 \\
Al (Wet) & 1536 & $124,706,810$ & 191,556 & 1816 \\
\hline Br (Dry) & 592 & $9,763,209$ & 5776 & 1467 \\
Br (Wet) & 406 & $9,763,209$ & 3960 & \\
\hline Cn (Dry) & 867 & $29,567,726$ & 25,647 & \\
Cn (Wet) & 818 & $29,567,726$ & 24,180 & 183 \\
\hline Wh (Dry) & 738 & $6,374,706$ & 4703 & \\
Wh (Wet) & 644 & $6,374,706$ & 4104 & \\
\hline Wh/So (Dry) & 1435 & $3,411,003$ & 4895 & \\
Wh/So (Wet) & 1381 & $3,411,003$ & 4712 & \\
\hline
\end{tabular}

Even though this approach shows how much more water was used in a dry year regarding each crop area coverage observed in the study area, the results fail to give the exact information on which crops used more water in gallons if each crop were grown in equal areas. Hence, the average area coverage for all five crops (i.e., the constant) was used for both dry and wet years and to compute the difference in water use between dry years and wet years to identify which crops used more water in relative terms. Single crops that used more water in dry years, in order from most to least, were barley, wheat, alfalfa, and corn (see Table 8). Even though barley used the least water in wet years, it consumed much more water in dry years. The difference between dry year and wet year water consumed by barley was the highest among all crops-186 mm in Table 2 (or total 6466 million liters in Table 8). Barley is the most tolerant cereal crop for drought and salinity. Other cereal crops may not survive or face problems in serious drought and saline conditions. During our meetings with irrigation district managers and local growers, we came to realize that barley is grown in districts where salinity is exceptionally high. For example, barley has the largest grown area in Buckeye district where the salinity is exceptional. Hence, growers need to pump a great deal of water to wash salt crust before preparing soil for crops. Salt crusts can even be seen clearly on topsoil (white layers). Again, saline water from groundwater aquifers is brought up to irrigate the crop again during the seedling stage. Local growers need to keep pumping excessive amounts of water so that salt on topsoil, saline water, and salinized soil does not affect crops severely. It is a must for local growers to pump significant amounts of water to wash heavily accumulated salt from topsoil continuously in a dry year. Since it is a drought and salt tolerant crop, they pump a great deal less water than other crops in a wet year. 
Table 8. Water saving by crops in wet years using a fixed crop area (average area of all crop types $)$ in both dry and wet years ( $\mathrm{Al}=$ Alfalfa; $\mathrm{Br}=$ Barley; $\mathrm{Cn}=\mathrm{Corn} ; \mathrm{Ct}=\mathrm{Cotton}$; Wh = Wheat; So $=$ Sorghum).

\begin{tabular}{|c|c|c|c|c|}
\hline $\begin{array}{l}\text { Crop Type } \\
\text { per Year }\end{array}$ & $\begin{array}{c}\begin{array}{c}\text { Water } \\
\text { Consumed } \\
\left(\text { Liter/m } / \mathbf{m}^{2}\right)\end{array}\end{array}$ & $\begin{array}{c}\text { Same Area } \\
\text { for } \\
\text { All Crops } \\
\left(\mathrm{m}^{2}\right)\end{array}$ & $\begin{array}{c}\text { Water } \\
\text { Consumed } \\
\text { (Million Liters) }\end{array}$ & $\begin{array}{c}\text { More Water } \\
\text { Consumed } \\
\text { in Dry Year } \\
\text { (Million Liters) }\end{array}$ \\
\hline Al (Dry) & 1616 & $34,764,691$ & 56,185 & 2785 \\
\hline Al (Wet) & 1536 & $34,764,691$ & 53,400 & \\
\hline Br (Dry) & 592 & $34,764,691$ & 20,565 & 6466 \\
\hline Br (Wet) & 406 & $34,764,691$ & 14,099 & \\
\hline Cn (Dry) & 867 & $34,764,691$ & 30,155 & 1725 \\
\hline Cn (Wet) & 818 & $34,764,691$ & 28,430 & \\
\hline Wh (Dry) & 738 & $34,764,691$ & 25,648 & 3268 \\
\hline Wh (Wet) & 644 & $34,764,691$ & 22,380 & \\
\hline Wh/So (Dry) & 1435 & $34,764,691$ & 49,887 & 1868 \\
\hline Wh/So (Wet) & 1381 & $34,764,691$ & 48,020 & \\
\hline
\end{tabular}

However, crops with higher water use in dry years must be judged by their total water use since, in a wet year, these types of crops save significant amounts of water. This demonstrates how important selecting crop types can be in drylands or arid and semi-arid areas if water conservation is the highest priority. This discussion illustrates why adaptation to drought is so challenging without some fundamental re-envisioning of the agricultural situation in the county. In the next section, some of these possibilities were examined.

\subsection{Comparing Water Consumption under Actual Versus Alternative Cropping Patterns}

The previous section showed the extent of water savings that are potentially available through shifts to less water intensive crops (e.g., barley), which are already being grown in the region. One of the reasons that a wider adoption of less water intensive crops in dry years is not considered is because water conservation may not be the only (or even the prime) driver for crop choice. Farmers' choice of crops to grow depends on a number of other factors, including climatic conditions, soil characteristics, crop rotation requirements, prices, access to markets, and availability of local processing infrastructure. For instance, the popularity of alfalfa in recent years stems from favorable market conditions and because of access to local dairies and other livestock operations that use it for feed. It is beyond the scope of this paper to explore in depth the determinants of crop choice. In the rest of this section, results from the ET estimations were used to show how much water savings are possible under alternative cropping pattern scenarios compared to the pattern observed during the study period.

\subsection{Actual Cropping Patterns and Corresponding Water Consumption during Study Period}

During the study period, alfalfa had the highest acreage in the Phoenix AMA and accounted for $42.55 \%$ of the total cropland (Table 9). Cotton was the second highest water intensive crop, which had the second largest acreage $\left(92,539,282 \mathrm{~m}^{2}\right)$ and covered around $30 \%$ of cropland, followed by corn, which covered $10.64 \%$. Table 9 shows that the total double cropping farm area (i.e., barley/cotton, wheat/cotton, and wheat/sorghum) covered only $6.94 \%\left(21,519,619 \mathrm{~m}^{2}\right)$ of the entire farmland in Phoenix AMA. As a single crop, barley had the smallest acreage $\left(5,818,505 \mathrm{~m}^{2}\right)$ and covered $1.88 \%$ of the farmland, followed by wheat $\left(25,306,822 \mathrm{~m}^{2}\right.$ and $\left.8.16 \%\right)$. Even though barley was found to consume the least amount of water among all crops, it had the lowest coverage $(1.88 \%$ of total farmland). Notably, the practice of double cropping, which was shown earlier to save significant amounts of water, was observed to cover only $6.94 \%$ of the farmland. Therefore, evidence was found for an emerging need to formulate policy, create incentives, and encourage local farmers to grow more double crops and fewer high water use crops. 
Table 9. Area by crop type.

\begin{tabular}{|c|c|c|c|c|c|c|}
\hline & $\begin{array}{l}2001 \\
\left(\mathrm{~m}^{2}\right)\end{array}$ & $\begin{array}{l}2002 \\
\left(\mathrm{~m}^{2}\right)\end{array}$ & $\begin{array}{l}2005 \\
\left(\mathrm{~m}^{2}\right)\end{array}$ & $\begin{array}{l}\text { Total } \\
\left(\mathrm{m}^{2}\right)\end{array}$ & $\begin{array}{c}\text { Average/yr } \\
\left(\mathrm{m}^{2}\right)\end{array}$ & \% Crop Area \\
\hline Alfalfa & $153,182,835$ & $124,706,810$ & $118,007,204$ & $395,896,850$ & $131,965,617$ & $42.55 \%$ \\
\hline Barley & - & 9,763,209 & $1,873,802$ & $11,637,010$ & $5,818,505$ & $1.88 \%$ \\
\hline Cotton & $121,825,908$ & $78,086,769$ & $77,705,169$ & $277,617,845$ & $92,539,282$ & $29.84 \%$ \\
\hline Corn & $34,850,731$ & $29,567,726$ & $34,597,831$ & $99,016,288$ & $33,005,429$ & $10.64 \%$ \\
\hline Wheat & $41,835,637$ & $6,374,706$ & $27,710,124$ & $75,920,467$ & $25,306,822$ & $8.16 \%$ \\
\hline Barley/Cotton & - & $9,223,208$ & - & $9,223,208$ & $9,223,208$ & $2.97 \%$ \\
\hline Wheat/Cotton & $8,838,908$ & $2,301,302$ & $2,616,302$ & $13,756,512$ & $4,585,504$ & $1.48 \%$ \\
\hline Wheat/Sorghum & $8,082,007$ & $3,411,003$ & $11,639,710$ & $23,132,720$ & $7,710,907$ & $2.49 \%$ \\
\hline
\end{tabular}

An important question to ask here is regarding how acreage under water intensive crops shifted between dry and wet years in the study period. If water availability is a binding constraint for farmers and an important determinant of crop choice, one would expect acreage under water intensive crops to be lower in dry years. Although, with just three years of data, one cannot really test this hypothesis, the data show just the opposite pattern. It was found that acreage for more water intensive crops (alfalfa and cotton) was greater in dry years (2002) relative to wet years (2005) (Figure 8). In contrast, lower water intensity single crops, such as corn and wheat, had lower acreage in dry years (2002) relative to wet years $(2001,2005)$. Similarly, acreage under lower water use double crops, such as wheat/cotton and wheat/sorghum, were also lower in dry years (2002) relative to wet years (2001 and 2005). This suggests that, during the study period, water conservation by itself was not an important determinant of crop choice.

In terms of the relative share of different crops in total crop water use in the region, alfalfa accounted for more than half (56.81\%) of the share, followed by cotton, which accounted for another quarter $(25.36 \%)$, and then corn $(8.01 \%)$, wheat $(3.35 \%)$, and barley $(0.97 \%)$ (Table 6). Double cropped wheat/sorghum and wheat/cotton accounted for only $3.11 \%$ and $2.40 \%$ of crop water use, respectively. This further points to the highly skewed cropping pattern in this desert region, with the two most water intensive crops accounting for more than three quarters of the total crop water use, while water conservation practices such as double cropping accounted for around $5 \%$ of water consumption.

\subsection{Water Saving Potential of Alternative Cropping Patterns: Replacing Alfalfa and Cotton with Wheat and Barley}

Since alfalfa and cotton used the highest amounts of water, it may be interesting to examine how much water could be saved if the cropping pattern over the agricultural year was changed. As mentioned before, crop choice is determined by many factors of which water conservation may not be a significant factor. However, as a thought experiment, it was designed to see what would happen if barley were grown in alfalfa crop areas and wheat in cotton areas in all three years studied. Barley and wheat were selected since they used the least water overall. Table 10 shows that, if the Phoenix AMA had replaced alfalfa and cotton with barley and wheat, respectively, the region would have saved 1836 million liters in 2001, 1462 million liters in 2002, and 1390 million liters of water in 2005. On average, the region would have saved approximately 1563 million liters of water per year for three years. This highlights that tremendous opportunities are available through crop selection and mixes that can significantly influence water saving and conserve sustainable agriculture, especially in arid and semi-arid areas. This finding is important for all agricultural areas in different climate regions because the world's climate is warmer than ever before [61], drought has intensified [62], water scarcity looms ever larger [63], and food security may soon diminish [64]. The IPCC's technical summary stressed the importance of water conservation in connection to policies governing practices in agriculture for the needs of both mitigation and adaptation and reported that water conservation is a key to food security in the 21st century [65]. 
Table 10. Example of water savings by switching crops $(\mathrm{Al}=\mathrm{Alfalfa} ; \mathrm{Ct}=\mathrm{Cotton} ; \mathrm{Br}=\mathrm{Barley} ; \mathrm{Wh}=\mathrm{Wheat})$.

\begin{tabular}{|c|c|c|c|c|c|c|c|c|c|}
\hline & $\begin{array}{c}\text { Water } \\
\text { (Million } \\
\text { Liters) } \\
2001\end{array}$ & $\begin{array}{c}\text { Water } \\
\text { (Million } \\
\text { Liters) } \\
2002\end{array}$ & $\begin{array}{c}\text { Water } \\
\text { (Million } \\
\text { Liters) } \\
2005\end{array}$ & $\begin{array}{c}\mathrm{Al}=>\text { Bar } \\
\text { Cot }=>\text { Wh } \\
\text { (Million } \\
\text { Liters) } \\
2001\end{array}$ & $\begin{array}{c}\mathrm{Al}=>\text { Bar } \\
\text { Cot }=>\text { Wh } \\
\text { (Million } \\
\text { Liters) } \\
2002\end{array}$ & $\begin{array}{c}\mathrm{Al}=>\text { Bar } \\
\text { Cot }=>\text { Wh } \\
\text { (Million } \\
\text { Liters) } \\
2005\end{array}$ & $\begin{array}{c}\text { Total } \\
\text { Saving } \\
\text { (Million } \\
\text { Liters) } \\
2001\end{array}$ & $\begin{array}{c}\text { Total } \\
\text { Saving } \\
\text { (Million } \\
\text { Liters) } \\
2002\end{array}$ & $\begin{array}{c}\text { Total } \\
\text { Saving } \\
\text { (Million } \\
\text { Liters) } \\
2005\end{array}$ \\
\hline $\mathrm{Al}$ & 2414 & 1966 & 1860 & & & & & & \\
\hline $\mathrm{Ct}$ & 1027 & 658 & 655 & & & & & & \\
\hline $\mathrm{Br}$ & - & 49 & 9 & 764 & 670 & 598 & & & \\
\hline Wh & 289 & 44 & 191 & 1130 & 583 & 728 & & & \\
\hline Total & 3730 & 2716 & 2715 & 1894 & 1254 & 1326 & 1836 & 1462 & 1390 \\
\hline
\end{tabular}

If the objective is water conservation, then priority needs to be given to crops that use less water, such as corn, wheat, and barley, especially in arid and semi-arid regions that experience serious droughts. Notably, the first two crops (i.e., alfalfa and cotton) that are associated with the highest water use rates are non-food crops for humans. If intensive water conservation becomes necessary when drought becomes a serious concern, non-food crops that consume a much higher amount of water than food crops should be discouraged.

\subsection{Identification of Excessive Water Consumption and Considerably Low Water Consumption Areas}

To determine excessive water consumption areas and considerably low water consumption areas in the study area, \pm 1 standard deviation (Std) of each crop was calculated. This was to map areas of excessive water consumption (above $1 \mathrm{Std}$ ) and considerably less water consumption (under $1 \mathrm{Std}$ ). This was to demonstrate areas where water was disproportionately consumed and determine the extent of extra water use agriculture areas by crop type and vice versa in both dry and wet years. This also shows how water use by crop varies across space and between dry and wet years. However, with regard to the areas of over-consumed water, the results may not necessarily imply that those areas above $1 \mathrm{Std}$ were overirrigated areas or inefficiently irrigated areas. From Table 11, it can be observed that water consumption for cotton varied the most in 2005 (wet year), since it had the highest Std (438.1). The variations of cotton water consumption for 2001 and 2002 were also consistently high. Even though variation of wheat water consumption in 2002 (dry year) was found to be the lowest (153.19), the variations in water consumption in wet years (2001 and 2005) were very high (i.e., 395.49, 384.59). Both types of double crops showed a consistent and reasonably low fluctuation in water consumption for all three years.

Table 11. Variation of water consumption (Std) by crop type.

\begin{tabular}{cccc}
\hline Crop Type & $\begin{array}{c}\mathbf{2 0 0 1}(\mathrm{ET}) \\
\text { (Std) }\end{array}$ & $\begin{array}{c}\mathbf{2 0 0 2} \text { (ET) } \\
\text { (Std) }\end{array}$ & $\begin{array}{c}\mathbf{2 0 0 5} \text { (ET) } \\
\text { (Std) }\end{array}$ \\
\hline Alfalfa & 371.21 & 294.22 & 377.04 \\
Barley & - & 276.46 & 340.25 \\
Corn & 296.31 & 270.75 & 434.08 \\
Cotton & 356.01 & 314.08 & 438.1 \\
Wheat & 395.49 & 153.19 & 384.59 \\
Wheat/Cotton & 262.09 & 248.29 & 200.47 \\
Wheat/Sorghum & 260.71 & 301.84 & 309.41 \\
\hline
\end{tabular}


In almost all cases, excessive water consumption areas had higher land coverage than considerably low water consumption areas (Table 12). Alfalfa had the largest coverage of excessive water consumption areas (2785 ha, $1488 \mathrm{ha}$, and $1182 \mathrm{ha})$ for all three years. It should also be noted that alfalfa also covered the largest considerably low water consumption areas (2447 ha, $1507 \mathrm{ha}$, and $977 \mathrm{ha}$ ). The only excessive water consumption (1453 ha) and considerably low water consumption areas (882 ha) belonged to cotton in 2001. Areas of excessive water consumption areas (391 ha, $238 \mathrm{ha}$ ) and considerably low water consumption areas (189 ha, $113 \mathrm{ha}$ ) were also fairly high in comparison to the other crops. Even though barley had the largest percentages for excessive water consumption areas $(29 \%)$ and considerably low water consumption areas (34\%) in 2005, its original area crop coverage was small.

Table 12. Notably excessive water consumption and considerably low water consumption areas by crop type.

\begin{tabular}{ccccccc}
\hline Crop Type & $\begin{array}{c}\text { 2001 (Over) } \\
\text { Ha (\%) }\end{array}$ & $\begin{array}{c}\text { 2001 (Stress) } \\
\text { Ha (\%) }\end{array}$ & $\begin{array}{c}\text { 2002 (Over) } \\
\text { Ha (\%) }\end{array}$ & $\begin{array}{c}\text { 2002 (Stress) } \\
\text { Ha (\%) }\end{array}$ & $\begin{array}{c}\text { 2005 (Over) } \\
\text { Ha (\%) }\end{array}$ & $\begin{array}{c}\text { 2005 (Stress) } \\
\text { Ha (\%) }\end{array}$ \\
\hline Alfalfa & $2785(18 \%)$ & $2447(16 \%)$ & $1488(12 \%)$ & $1507(12 \%)$ & $1182(10 \%)$ & $977(8 \%)$ \\
Barley & - & - & $124(13 \%)$ & $58(6 \%)$ & $55(29 \%)$ & $63(34 \%)$ \\
Corn & $444(13 \%)$ & $138(4 \%)$ & $300(10 \%)$ & $175(6 \%)$ & $402(12 \%)$ & $8.46(<1 \%)$ \\
Cotton & $1453(12 \%)$ & $882(7 \%)$ & $391(5 \%)$ & $189(2 \%)$ & $238(3 \%)$ & $113(1 \%)$ \\
Wheat & $775(19 \%)$ & $243(6 \%)$ & $101(16 \%)$ & $90(14 \%)$ & $654(24 \%)$ & $441(16 \%)$ \\
Wheat/Cotton & $170(19 \%)$ & $162(18 \%)$ & $34(15 \%)$ & $41(18 \%)$ & $35(13 \%)$ & $45(17 \%)$ \\
Wheat/Sorghum & $144(18 \%)$ & $131(16 \%)$ & $77(22 \%)$ & $44(13 \%)$ & $179(15 \%)$ & $136(12 \%)$ \\
\hline
\end{tabular}

Figure 9 shows areas of excessive water consumption and considerably low water consumption areas in blue and red, respectively, for 2001, 2002, and 2005. In general, excessive water consumption areas were found in the western part of the Phoenix AMA (e.g., ARLINGTON, BUCKEYE, ROOSID), whereas considerably low water consumption areas occurred mostly in two irrigation districts in the east side of the area (e.g., QCID, RWCD). With regard to water conservation and management, the irrigation districts stated above need considerable attention, especially for overly consumed areas. Moreover, there is a need to investigate drivers of highly fluctuated water-consuming crops and excessive water-consuming crops in connection to crop yield for efficient water use and better water conservation. 


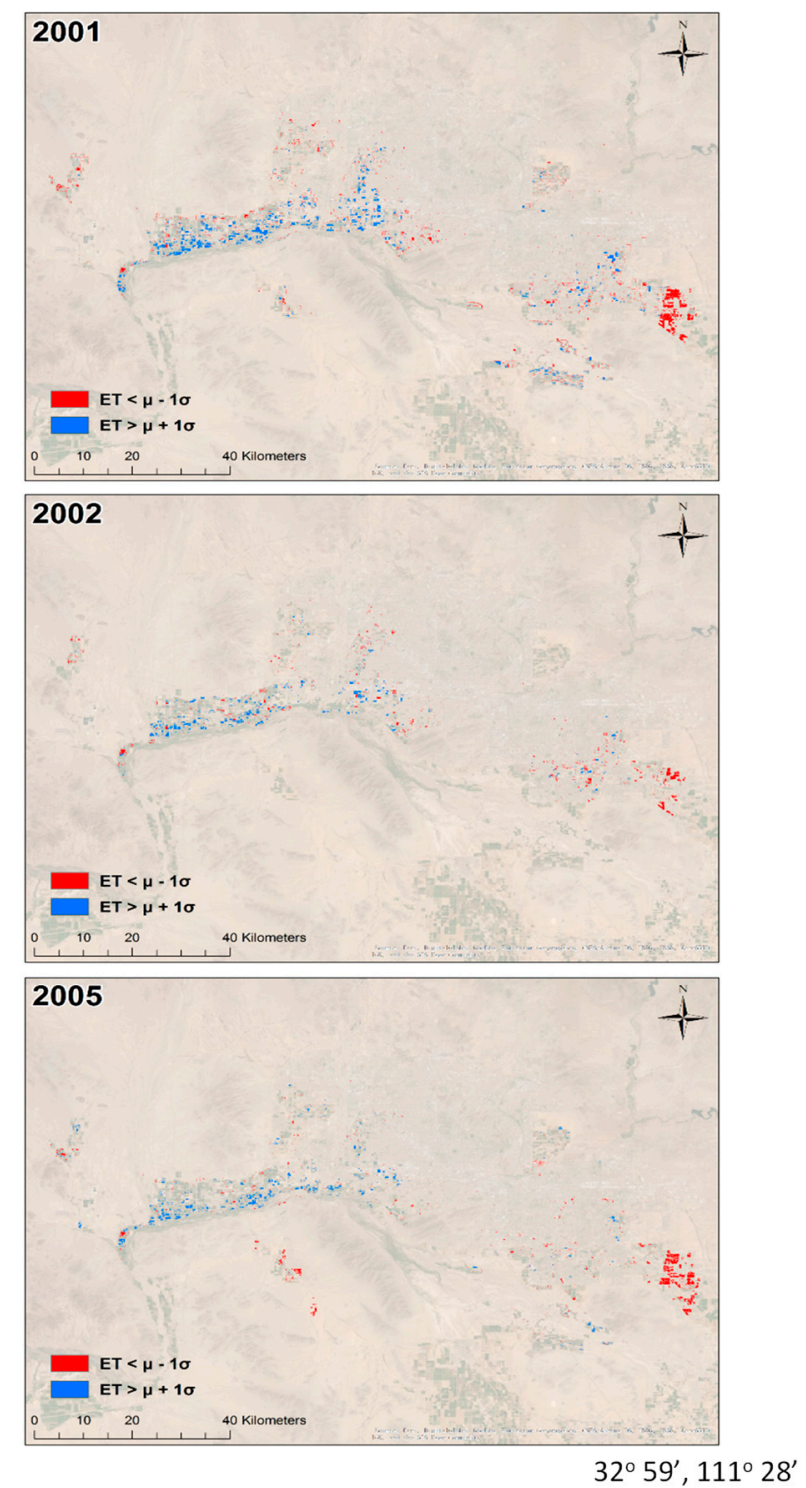

Figure 9. Excessive water consumption and considerably low water consumption areas for 2001, 2002, and 2005.

\section{Conclusions}

The strong correlations between the estimated ET and the reported agricultural water use data at the irrigation district level $\left(R^{2}=0.98\right)$ and the farm unit level $\left(R^{2}=0.78\right)$ demonstrate the use of satellite derived ET data for effectively estimating agricultural water use. Due to variations in soil conditions, water quality, farm management practices, and microclimate, water use efficiency can vary from one farm unit to another. The irrigation districts with relatively low $\mathrm{R}^{2}$ scores demonstrate that predicted ET values were slightly lower than actual water use. However, the relationships between ET estimated by the METRIC model and actual water use were strong with $R^{2}$ above 0.72 for all the irrigation districts except STJOHNS $\left(R^{2}=0.5\right)$.

Results from this study offer several options and implications for climate adaptation with regard to water conservation, including that (1) crops use more water in dry years in irrigated areas if water availability is not a binding constraint; (2) double cropping practice uses substantially less water than the same two crops in two different areas as single crops; (3) crop selection is vital in water conservation for future food security, because some crop types use almost double the amount of water that other crop types do; (4) consideration of 
drought tolerant crop types is crucial in future water management since some crops use notably higher amounts of water in dry years even though they may consume much less water than other crop types do overall; (5) selection of single crops and double crops in dry years is also important in saving water; (6) disproportionately large area coverage of high water consuming crops needs to be balanced and/or reduced in the area studied or replaced with other more water efficient crops; and (7) reduction of total crop area coverage may not be necessary, and extension of agriculture can even be considered for sustainable water conservation in critical agricultural production areas if lower water use crop types, drought tolerant crops, and double and/or multiple cropping practices are employed.

Overall, our results highlight that, from the perspective of water conservation, beyond the traditional management tools of controlling total crop area and crop water use, crop selection and mixing as well as double and multiple cropping practices are important strategies for water conservation in drought-sensitive regions. This study provides strong evidence for an emerging need to formulate policy and create incentives for adopting smart cropping strategies. The satellite data-based ET estimates of water consumption presented in this study provide a rigorous basis for providing important guidelines for sustainable agriculture management and climate adaption to improve future food security.

Author Contributions: Conceptualization, S.W.M., R.A., E.A.W. and J.H.; methodology, S.W.M., R.A.; software, B.Z., C.F. and C.W.; validation, B.Z.; formal analysis, S.W.M., R.A., B.Z., C.F. and C.W.; data curation, S.W.M., B.Z., C.W., R.A. and N.J.S.; writing-original draft preparation, S.W.M., R.A. and B.Z.; writing-review and editing, S.W.M., R.A., B.Z., C.F., E.A.W., J.H., C.W. and H.A.F.; visualization, S.W.M., B.Z., C.F., C.W.; supervision, S.W.M., R.A.; funding acquisition, S.W.M., R.A., E.A.W., N.J.S. and J.H. All authors have read and agreed to the published version of the manuscript.

Funding: The study was funded by National Oceanic and Atmospheric Administration (grant number: NA12OAR4310100). We also would like to acknowledge the support by National Science Foundation under grant number DEB-1026865 for Central Arizona-Phoenix Long-Term Ecological Research (CAPLTER), grant numbers SES-0951366 \& SES-0345945 for Decision Center for a Desert City (DCDC), grant number CNS-1639227 for INFEWS/T2: Flexible Model Compositions and Visual Representations for Planning and Policy Decisions at the Sub-regional level of the food-energywater nexus.

Data Availability Statement: The data reported in this manuscript were generated by the team of this research study funded by National Oceanic and Atmospheric Administration (grant number: NA12OAR4310100). Since voluminous data were used in this study, we have not yet posted the data on a website and do not have any web link. Correspondence and requests for materials, including 1095 ET maps, 3 crop type maps, and 92 Landsat NDVI data, should be addressed to Soe W. Myint who serves as Principal Investigator of the above mentioned NOAA funded project.

Acknowledgments: Thanks are due to Christina Day (Maricopa County Farm Service Agency) and several local growers, including Ron Rayner, Adam Hatley, Marvin John, Steve Sossaman, W. T. Gladden, and Brandon Brooks, for answering our survey questions and providing ground reference data as well. We also would like to express our appreciation to Bill Plummer and Chris Udall from AgriBusiness and Water Council of Arizona for jointly organizing the two workshops, setting up meetings with local growers and irrigation district managers, and providing relevant documents and suggestions throughout the project period. We also appreciate Dianne Yunker (Arizona Department of Water Resources) for providing data and reports as well as setting up meetings with relevant parties at the Arizona Department of Water Resources and providing suggestions for the study.

Conflicts of Interest: The authors declare no conflict of interest.

\section{References}

1. $\quad$ Easterling, D.R.; Kunkel, K.E.; Arnold, J.R.; Knutson, T.; LeGrande, A.N.; Leung, L.R.; Vose, R.S.; Waliser, D.E.; Wehner, M.F. Precipitation Changes in the United States. In Climate Science Special Report: Fourth National Climate Assessment (NCA4); Wuebbles, D.J., Fahey, D.W., Hibbard, K.A., Dokken, D.J., Stewart, B.C., Maycock, T.K., Eds.; Global Change Research Program: Washington, DC, USA, 2017; Volume I, pp. 207-230.

2. Christensen, J.H.; Hewitson, B.; Busuioc, A.; Chen, A.; Gao, X.; Held, I.; Jones, R.; Kolli, R.K.; Kwon, W.T.; Laprise, R.; et al. Regional Climate Projections. In Climate Change, 2007: The Physical Science Basis. Contribution of Working Group I to the Fourth 
Assessment Report of the Intergovernmental Panel on Climate Change; Solomon, S., Qin, D., Manning, M., Chen, Z., Marquis, M., Averyt, K.B., Tignor, M., Miller, H.L., Eds.; Cambridge University Press: Cambridge, UK; New York, NY, USA, 2007; pp. 847-940.

3. Barnett, T.P.; Pierce, D.W.; Hidalgo, H.G.; Bonfils, C.; Santer, B.D.; Das, T.; Bala, G.; Wood, A.W.; Nozawa, T.; Mirin, A.A.; et al. Human-induced changes in the hydrology of the western United States. Science 2008, 319, 1080-1083. [CrossRef] [PubMed]

4. Rauscher, S.A.; Pal, J.S.; Diffenbaugh, N.S.; Benedetti, M.M. Future changes in snowmelt-driven runoff timing over the western United States. Geophys. Res. Lett. 2008, 35, L16703. [CrossRef]

5. Karl, T.R.; Melillo, J.M.; Peterson, T.C. Global Climate Change Impacts in the United States; Cambridge University Press: New York, NY, USA, 2009.

6. Woodhouse, C.A.; Gray, S.T.; Meko, D.M. Updated streamflow reconstructions for the upper Colorado River basin. Water Resour. Res. 2006, 42, W05415. [CrossRef]

7. Meko, D.M.; Woodhouse, C.A.; Basisan, C.A.; Knight, T.; Lukas, J.J.; Hughes, M.K.; Salzer, M.W. Medieval drought in the upper Colorado River basin. Geophys. Res. Lett. 2007, 34, L10705. [CrossRef]

8. Bonfils, C.; Santer, B.D.; Pierce, D.W.; Hidalgo, H.G.; Bala, G.; Das, T.; Barnett, T.P.; Cayan, D.R.; Doutriaux, C.; Wood, A.W.; et al. Detection and attribution of temperature changes in the mountainous western United States. J. Clim. 2008, 21, 6404-6424. [CrossRef]

9. U.S. Department of Agriculture (USDA). Regional Conservation Partnership Program, Colorado River Basin; Natural Resources Conservation Service, USDA: Washington, DC, USA, 2014. Available online: https://www.nrcs.usda.gov/wps/portal/nrcs/ detailfull/co/programs/farmbill/rcpp/?cid=nrcseprd1316414 (accessed on 8 April 2021).

10. Lapola, D.M.; Oyama, M.D.; Nobre, C.A. Exploring the range of climate biome projections for tropical South America: The role of $\mathrm{CO}_{2}$ fertilization and seasonality. Glob. Biogeochem. Cycles 2009, 23, GB3003. [CrossRef]

11. Stahlschmidt, Z.R.; DeNardo, D.F.; Holland, J.N.; Kotler, B.P.; Kruse-Peeples, M. Tolerance mechanisms in North American deserts: Biological and societal approaches to climate change. J. Arid. Environ. 2011, 75, 681-687. [CrossRef]

12. Holmgren, M.; Stapp, P.; Dickman, C.R.; Gracia, C.; Graham, S.; Gutierrez, J.R.; Hice, C.; Jaksic, F.; Kelt, D.A.; Letnic, M.; et al. Extreme climatic events shape arid and semiarid ecosystems. Front. Ecol. Environ. 2006, 4, 87-95. [CrossRef]

13. Vörösmarty, C.J.; Green, P.; Salisbury, J.; Lammers, R.B. Global water resources: Vulnerability from climate change and population growth. Science 2000, 289, 284-288. [CrossRef]

14. Malmqvist, B.; Rundle, S.D.; Covich, A.P.; Hildrew, A.G.; Robinson, C.T.; Townsend, C.R. Prospects for streams and rivers: An ecological perspective. In Aquatic Ecosystems: Trends and Global Prospects; Polunin, N.V.C., Ed.; Cambridge University Press: Cambridge, UK, 2008; pp. 19-29.

15. Dise, N.B. Peatland response to global change. Science 2009, 326, 810-811. [CrossRef] [PubMed]

16. Smith, R.G.; Knight, R.; Chen, J.; Reeves, J.A.; Zebker, H.A.; Farr, T.; Liu, Z. Estimating the permanent loss of groundwater storage in the southern San Joaquin Valley, California. Water Resour. Res. 2017, 53, 2133-2148. [CrossRef]

17. Garfin, G.; Franco, G.; Blanco, H.; Comrie, A.; Gonzalez, P.; Piechota, T.; Smyth, R.; Waskom, R. Ch. 20: Southwest. In Climate Change Impacts in the United States: The Third National Climate Assessment; Melillo, J.M., Richmond, T.T.C., Yohe, G.W., Eds.; U.S. Global Change Research Program: Washington, DC, USA, 2014; pp. 462-486.

18. U.S. Department of Agriculture (USDA). Farm and Ranch Irrigation Survey (2008). In 2007 Census of Agriculture; Special Studies, Part 1.; U.S. Department of Agriculture: Washington, DC, USA, 2008; Volume 3.

19. Kenny, J.F.; Barber, N.L.; Hutson, S.S.; Linsey, K.S.; Lovelace, J.K.; Maupin, M.A. Estimated Use of Water in the United States in 2005. U.S. Geol. Surv. Circ. 2009, 1344, 52.

20. Amarasinghe, U.A.; Smakhtin, V.U. Global water demand projections: Past, present and future. In IWMI Research Report 156; International Water Management Institute (IWMI): Colombo, Sri Lanka, 2014.

21. Flörke, M.; Schneider, C.; McDonald, R. Water competition between cities and agriculture driven by climate change and urban growth. Nat. Sustain. 2018, 1, 51-58. [CrossRef]

22. Lundquist, J.D.; Loheide II, S.P. How evaporative water losses vary between wet and dry water years as a function of elevation in the Sierra Nevada, California, and critical factors for modeling. Water Resour. Res. 2011, 47, W00H09. [CrossRef]

23. Goldstein, A.H.; Hultman, N.E.; Fracheboud, J.M.; Bauer, M.R.; Panek, J.A.; Xu, M.; Qi, Y.; Guenther, A.B.; Baugh, W. Effects of climate variability on the carbon dioxide, water, and sensible heat fluxes above a ponderosa pine plantation in the Sierra Nevada (CA). Agric. For. Meteorol. 2000, 101, 113-129. [CrossRef]

24. Hamlet, A.F.; Mote, P.W.; Clark, M.P.; Lettenmaier, D.P. Twentieth-century trends in runoff, evapotranspiration, and soil moisture in the Western United States. J. Clim. 2007, 20, 1468-1485. [CrossRef]

25. Arizona Department of Water Resources (ADWR). Arizona Water Atlas_Volume 8-Active Management Area Planning Area; 2010 Available online: https:/ / www.resolutionmineeis.us/sites/default/files/references/adwr-arizona-water-atlas-vol-8-2010.pdf (accessed on 8 April 2021).

26. U.S. Department of Agriculture (USDA)—Natural Resources Conservation Service (NRCS). Land Resource Regions and Major Land Resource Areas of the United States, the Caribbean, and the Pacific Basin (USDA Handbook 296); 2006. Available online: https: / / www.nrcs.usda.gov/Internet/FSE_DOCUMENTS/nrcs142p2_051845.pdf (accessed on 21 March 2021).

27. Hendrickx, J.M.H.; Hong, S.H. Mapping sensible and latent heat fluxes in arid areas using optical imagery. Proc. Int. Soc. Opt. Eng. SPIE 2005, 5811, 138-146. 
28. Kaplan, S.; Myint, S.W. Estimating agricultural water use through Landsat TM and a simplified surface energy balance modeling in the semi-arid environments of Arizona. Photogramm. Eng. Remote. Sens. 2012, 78, 849-859. [CrossRef]

29. Wang, C.; Turner, V.K.; Wentz, E.A.; Zhao, Q.; Myint, S.W. Optimization of residential green space for environmental sustainability and property appreciation in metropolitan Phoenix, Arizona. Sci. Total Environ. 2021, 763, 144605. [CrossRef] [PubMed]

30. Allen, R.G.; Tasumi, M.; Morse, A.; Trezza, R.; Kramber, W.; Lorite, I. Satellite-based energy balance for mapping evapotranspiration with internalized calibration (METRIC)—Applications. J. Irrig. Drain. Eng. 2007, 133, 395-406. [CrossRef]

31. Bastiaanssen, W.G.M.; Ahmad, M.D.; Chemin, Y. Satellite surveillance of evaporative depletion across the Indus Basin. Water Resour. Res. 2002, 38, 1273. [CrossRef]

32. Hong, S.H.; Hendrickx, J.M.H.; Borchers, B. Effect of scaling transfer between evapotranspiration maps derived from LandSat 7 and MODIS images. Proc. Int. Soc. Opt. Eng. SPIE 2005, 5811, 147-158.

33. Hafeez, M.; Andreini, M.; Liebe, J.; Friesen, J.; Marx, A.; Giesen, N.V.D. Hydrological parameterization through remote sensing in Volta Basin, West Africa. Int. J. River Basin Manag. 2006, 4, 1-8. [CrossRef]

34. Hong, S.H.; Hendrickx, J.M.H.; Borchers, B. Up-scaling of SEBAL derived evapotranspiration maps from Landsat (30 m) to MODIS (250 m) scale. J. Hydrol. 2009, 370, 122-138. [CrossRef]

35. Hong, S.H.; Hendrickx, J.M.H.; Borchers, B. Downscaling of SEBAL derived evapotranspiration map from MODIS (250 m) to Landsat (30 m) scale. Int. J. Remote Sens. 2011, 32, 6457-6477. [CrossRef]

36. Allen, R.G.A.; Irmak, A.; Trezza, R.; Hendrickx, J.M.H.; Bastiaanssen, W.G.M.; Kjaersgaard, J. Satellite-based ET estimation in agriculture using SEBAL and METRIC. Hydrol. Process. 2011, 25, 4011-4027. [CrossRef]

37. Hendrickx, J.M.H.; Allen, R.G.; Brower, A.; Byrd, A.R.; Hong, S.H.; Ogden, F.L.; Pradhan, N.R.; Robison, C.W.; Toll, D.; Trezza, R.; et al. Benchmarking optical/thermal satellite imagery for estimating evapotranspiration and soil moisture in decision support tools. J. Am. Water Resour. Assoc. 2016, 52, 89-119. [CrossRef]

38. Bastiaanssen, W.G.M.; Menenti, M.; Feddes, R.A.; Holtslag, A.A.M. A remote sensing surface energy balance algorithm for land (SEBAL): 1. Formulation. J. Hydrol. 1998, 212, 198-212. [CrossRef]

39. Allen, R.G.; Burnett, B.; Kramber, W.; Huntington, J.; Kjaersgaard, J.; Kilic, A.; Kelly, C.; Trezza, R. Automated calibration of the METRIC-Landsat evapotranspiration process. J. Am. Water Resour. Assoc. 2013, 49, 563-576. [CrossRef]

40. Bastiaanssen, W.G.W.; Noordman, E.J.M.; Pelgrum, H.; Davids, G.; Thoreson, B.P.; Allen, R.G. SEBAL model with remotely sensed data to improve water-resources management under actual field conditions. J. Irrig. Drain. Eng. 2005, 131, 85-93. [CrossRef]

41. Allen, R.G.; Tasumi, M.; Trezza, R. Satellite-based Energy Balance for Mapping Evapotranspiration with Internalized Calibration (METRIC)-Model. J. Irrig. Drain. Eng. 2007, 133, 380-394. [CrossRef]

42. Trezza, R. Evapotranspiration Using a Satellite-Based Surface Energy Balance with Standardized Ground Control. Ph.D. Thesis, Utah State University, Logan, UT, USA, 2002.

43. Allen, R.G.; Walter, I.A.; Elliott, R.; Howell, T.; Itenfisu, D.; Jensen, M. The ASCE Standardized Reference Evapotranspiration Equation; 2005. Available online: https:/ /xwww.mesonet.org/images/site/ASCE_Evapotranspiration_Formula.pdf (accessed on 8 April 2021).

44. Zheng, B.; Myint, S.W.; Thenkabail, P.S.; Aggarwal, R. A support vector machine to identify irrigated crop types using time-series Landsat NDVI data. Int. J. Appl. Earth Obs. Geoinf. 2015, 34, 103-112. [CrossRef]

45. Foody, G.M.; Mathur, A. Toward intelligent training of supervised image classifications: Directing training data acquisition for SVM classification. Remote Sens. Environ. 2004, 93, 107-117. [CrossRef]

46. Plaza, A.; Benediktsson, J.A.; Boardman, J.W.; Brazile, J.; Bruzzone, L.; Camps-Valls, G.; Chanussot, J.; Fauvel, M.; Gamba, P.; Gualtieri, A.; et al. Recent advances in techniques for hyperspectral image processing. Remote Sens. Environ. 2009, 113, S110-S122. [CrossRef]

47. Shao, Y.; Lunetta, R.S. Comparison of support vector machine, neural network, and CART algorithms for the land-cover classification using limited training data points. ISPRS J. Photogramm. Remote Sens. 2012, 70, 78-87. [CrossRef]

48. Congalton, R.; Green, K. Assessing the Accuracy of Remotely Sensed Data: Principles and Practices, 2nd ed.; CRC Press: Boca Raton, FL, USA, 2008.

49. Morse, A.; Kramber, W.J.; Allen, R. Cost comparison for monitoring irrigation water use: Landsat thermal data versus power consumption data. In Proceedings of the Pecora 17-The Future of Land Imaging Going Operational. Annual Meeting of the American Society of Photogrammetry and Remote Sensing, Denver, CO, USA, 18-20 November 2008.

50. Wang, H.; Zhang, L.; Dawes, W.R.; Liu, C. Improving water use efficiency of irrigated crops in the North China PlainMeasurements and modelling. Agric. Water Manag. 2001, 48, 151-167. [CrossRef]

51. U.S. Department of Agriculture (USDA)—National Agricultural Statistics Service (NASS). 2004 Arizona Agricultural Statistics Bulletin; 2004. Available online: https://www.nass.usda.gov/Statistics_by_State/Arizona/Publications/Annual_Statistical_ Bulletin/historical_bulletins/2004FullBulletin.pdf (accessed on 21 March 2021).

52. Fleck, B.E. Factors Affecting Agricultural Water Use and Sourcing in Irrigation Districts of Central Arizona. Master's Thesis, University of Arizona, Tucson, Arizona, 2013.

53. Hunt, P.G.; Bauer, P.J.; Matheny, T.A. Crop production in a wheat-cotton doublecrop rotation with conservation tillage. J. Prod. Agric. 1997, 10, 462-465. [CrossRef]

54. Zhang, Y.; Kendy, E.; Qiang, Y.; Changming, L.; Yanjun, S. Effect of soil water deficit on evapotranspiration, crop yield, and water use efficiency in the North China Plain. Agric. Water Manag. 2004, 64, 107-122. [CrossRef] 
55. Foulia, Y.; Duikerb, S.W.; Fritton, D.D.; Hallb, M.H.; Watsond, J.E.; Johnsone, D.H. Double cropping effects on forage yield and the field water balance. Agric. Water Manag. 2012, 115, 104-117. [CrossRef]

56. Unger, P.W.; Vigil, M.F. Cover crop effects on soil water relationships. J. Soil Water Conserv. 1998, 53, $200-207$.

57. Gregory, M.M.; Shea, K.L.; Bakko, E.B. Comparing agroecosystems: Effects of cropping and tillage patterns on soil, water, energy use and productivity. Renew. Agric. Food Syst. 2005, 20, 81-90. [CrossRef]

58. Joyce, B.A.; Wallender, W.W.; Mitchell, J.P.; Huyck, L.M.; Temple, S.R.; Brostrom, P.N.; Hsiao, T.C. Infiltration and soil water storage under winter cover cropping in California's Sacramento Valley. Trans. Am. Soc. Agric. Eng. 2002, 45, 315-326. [CrossRef]

59. Blake, C. Minimum Tillage Spells Success for Arizona's Ron Rayner; Western Farm Press: Fresno, CA, USA, 2018.

60. Frisvold, B.F. Developing Sustainability Metrics for Water Use in Arizona Small Grain Production; Final Report to the Arizona Grain Research and Promotion Council: Tucson, AZ, USA, 2015; p. 20.

61. Intergovernmental Panel on Climate Change (IPCC). Climate Change 2014: Synthesis Report; 2014. Available online: https: //reliefweb.int/sites/reliefweb.int/files/resources/SYR_AR5_FINAL_full.pdf (accessed on 21 March 2021).

62. Olesen, J.E.; Trnka, M.; Kersebaum, K.; Skjelvåg, A.; Seguin, B.; Peltonen-Sainio, P.; Rossi, F.; Kozyra, J.; Micale, F. Impacts and adaptation of European crop production systems to climate change. Eur. J. Agron. 2011, 34, 96-112. [CrossRef]

63. Lobell, D.B.; Hammer, G.L.; McLean, G.; Messina, C.; Roberts, M.J.; Schlenker, W. The critical role of extreme heat for maize production in the United States. Nat. Clim. Chang. 2013, 3, 497-501. [CrossRef]

64. Porter, J.R.; Xie, L.; Challinor, A.J.; Cochrane, K.; Howden, S.M.; Iqbal, M.M.; Lobell, D.B.; Travasso, M.I. Chapter 7: Food Security and Food Production Systems. In Climate Change 2014: Impacts, Adaptation, and Vulnerability. Part. A: Global and Sectoral Aspects. Contribution of Working Group II to the Fifth Assessment Report of the Intergovernmental Panel on Climate Change; Field, C.B., Barros, V., Dokken, D., Mach, K., Mastrandrea, M., Bilir, T., Chatterjee, M., Ebi, K., Estrada, Y., Genova, R., et al., Eds.; Cambridge University Press: Cambridge, UK; New York, NY, USA, 2014; pp. 485-533.

65. Edenhofer, O.; Pichs-Madruga, R.; Sokona, Y.; Minx, J.; Farahani, E.; Kadner, S.; Seyboth, K.; Adler, A.; Baum, I.; Baum, S.; et al. Technical Summary. In Climate Change 2014: Mitigation of Climate Change. Contribution of Working Group III to the Fifth Assessment Report of the Intergov-ernmental Panel on Climate Change; Edenhofer, O., Pichs-Madruga, R., Sokona, Y., Minx, J., Farahani, E., Kadner, S., Seyboth, K., Adler, A., Baum, I., Baum, S., et al., Eds.; Cambridge University Press: Cambridge, UK; New York, NY, USA, 2014; pp. 33-110. 